\title{
IGF-I GOVERNS CORTICAL INHIBITORY SYNAPTIC PLASTICITY BY ASTROCYTE ACTIVATION
}

José Antonio Noriega-Prieto ${ }^{1,7}$, Laura Eva Maglio ${ }^{1,2}$, Jonathan A. ZegarraValdivia $^{3,4,5}$, Jaime Pignatelli, ${ }^{3,4}$, Ana M. Fernandez ${ }^{3,4}$, Laura MartinezRachadell $^{3,4}$, Jansen Fernandes ${ }^{3,6}$, Ángel Núñez ${ }^{1}$, Alfonso Araque ${ }^{7}$, Ignacio Torres Alemán ${ }^{3,4}$, and David Fernández de Sevilla ${ }^{{ }^{*}}$

${ }^{1}$ Departamento de Anatomía, Histología y Neurociencia, Facultad de Medicina, Universidad Autónoma de Madrid, Madrid, 28029, Spain

${ }^{2}$ Departamento de Ciencias Médicas Básicas-Área Fisiología, Facultad de Medicina, Universidad de La Laguna, Tenerife, Spain.

${ }^{3}$ Instituto Cajal, Consejo Superior de Investigaciones Científicas, Madrid, Spain

${ }^{4}$ CIBERNED, Madrid, Spain.

${ }^{5}$ Universidad Nacional de San Agustín de Arequipa, Perú.

${ }^{6}$ Universidade Federal de São Paulo, Brazil.

${ }^{7}$ Department of Neuroscience, University of Minnesota, Minneapolis, Minnesota, USA.

*Address correspondence to David Fernández de Sevilla, Departamento de Anatomía, Histología y Neurociencia, Facultad de Medicina, Universidad Autónoma de Madrid, c/ Arzobispo Morcillo, 4, 28029, Madrid, Spain. Email: david.fernandezdesevilla@uam.es.

Key words: IGF-I, Astrocytes, LTD of the IPSCs, Adenosine Receptors, sensory discrimination 


\begin{abstract}
Insulin-like growth factor-I (IGF-I) signaling plays key regulatory roles in multiple processes of brain physiology and pathology. While the direct effects of IGF-I in neurons have been extensively studied, the astrocyte involvement in IGF-I signaling and the consequences on synaptic plasticity and animal behavior remain unknown. Here we show that IGF-I induces the long-term depression (LTD) of inhibitory synaptic transmission in the mouse barrel cortex. This LTD requires the activation of the IGF-I receptor (IGF-IR) in astrocytes, which stimulates astrocyte $\mathrm{Ca}^{2+}$ signaling and the release of $\mathrm{ATP} /$ adenosine that in turn activates $\mathrm{A}_{2 \mathrm{~A}}$ adenosine receptors at presynaptic inhibitory terminals. Specific deletion of IGF-IR in cortical astrocytes (IGF-IR ${ }^{-/}$) impaired the behavioral performance in a whisker discrimination task. These results show novel mechanisms and functional consequences of IGF-I signaling on cortical inhibitory synaptic plasticity and animal behavior, revealing astrocytes as key elements in these processes.
\end{abstract}

\title{
INTRODUCTION
}

Insulin-like growth factor-I (IGF-I) is a peptide with well-known trophic functions. IGF-I is actively transported to the central nervous system (CNS) from plasma through the blood-brain barrier (1)(2), and is also locally produced by neurons and glial cells (3)(4)(5). IGF-I regulates neuronal firing (6)(7) and modulates excitatory synaptic transmission in many areas of the central nervous system $(8)(9)(10)(11)(12)$. IGF-I also produces a long-lasting depression of glutamate-mediated GABA release by Purkinje cells in the cerebellum (10), or a long-term potentiation of GABA release in the olfactory bulb (13). However, whether IGF-I modulates inhibitory synaptic transmission in the neocortex remains unexplored. 
Astrocytes have emerged as active elements directly involved in synaptic physiology. They respond with $\mathrm{Ca}^{2+}$ elevations to neurotransmitters released by neurons and induce changes in neuronal excitability and synaptic transmission by releasing gliotransmitters $(14)(15)(16)(17)(18)(19)(20)$. Astrocytes can release a variety of trophic factors that promote neuronal survival, including IGF-I (21), and several studies have shown the presence of IGF-I and IGF-IRs in neurons, astrocytes and microglia $(22)(23)(24)(5)$. Indeed, IGF-I regulates astrocytic glucose control and CNS glucose metabolism (25), exerts proliferative effects on astrocytes (26), and reduces their cAMP levels(27). Activation of $\mathrm{GABA}_{\mathrm{B}} \mathrm{Rs}$ in astrocytes induce release of glutamate that potentiates both inhibitory (28) and excitatory (29) synaptic transmission. In addition to glutamate, astrocytes release ATP that in turn depresses excitatory synaptic transmission in the hippocampus (30)(31)(32). Moreover, in the neocortex, exocytosis of ATP from astrocytes leads to a short term down regulation of inhibitory synaptic currents by inhibiting postsynaptic and extrasynaptic $\mathrm{GABA}_{\mathrm{A}}$ receptors in layer $2 / 3$ pyramidal neurons (33).

Here, we investigated whether IGF-IR activation on astrocytes induces longterm modulation of inhibitory synaptic transmission at layer $2 / 3$ pyramidal neurons of the barrel cortex. We found that IGF-I induces a presynaptic LTD of IPSCs that depends on cytosolic calcium increases in astrocytes, and activation of $\mathrm{A}_{2 \mathrm{~A}}$ adenosine receptors. This LTD of inhibitory synaptic transmission is absent in mice in which IGFIR has been deleted specifically in astrocytes (IGF-IR ${ }^{-/-}$mice). In addition, we demonstrate that these IGF-IR ${ }^{-/-}$mice show an impairment in the performance of a whisker discrimination task. Therefore, our results demonstrate a novel mechanism of long-term synaptic depression of inhibition at the barrel cortex induced by activation of astrocytic IGF-IRs and ATP/Adenosine (ATP/Ado) release from astrocytes that have 
important consequences in the processing of somatosensory information occurring during the whisker discrimination task.

\section{RESULTS}

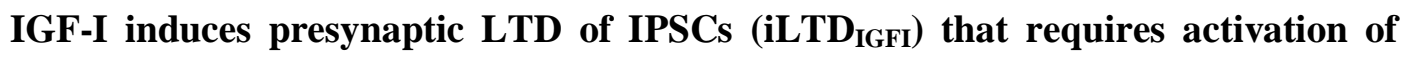 astrocytes.}

We first investigated whether IGF-I modulates the efficacy of inhibitory synaptic transmission at layer $2 / 3$ pyramidal neurons of the barrel cortex. Inhibitory postsynaptic currents (IPSCs) evoked by stimulation of layer 4 were recorded in layer $2 / 3$ neurons. IPSCs were isolated in the presence of the glutamate receptor antagonists $20 \mu \mathrm{M}$ CNQX and $50 \mu \mathrm{M}$ AP5 (Figure 1A). After 5 min of IPSC recording, IGF-I (10 nM) was bath applied during $35 \mathrm{~min}$ and then washed-out (Figure 1B). IGF-I induced a long-term depression (LTD) of the IPSCs peak amplitude (termed iLTD IGFI) that persisted after IGF-I washout (from $100.6 \pm 1.42$ to $60.73 \pm 5.08 \%$ of IPSC peak amplitude, before and after IGF-I. $\mathrm{N}=7, \mathrm{P}<0.001$; Figure 1B, black circles). These IGF-I-induced effects were prevented by bath perfusion of the IGF-IR selective inhibitor NVP-AEW 541 (from $98.72 \pm 0.50$ to $96.15 \pm 3.59 \%$ of IPSC peak amplitude, before and after IGF-I. $\mathrm{N}=7, \mathrm{P}=0.50$; Figure $1 \mathrm{~B}$, white circles), indicating that were mediated by IGF-IR activation.

Because postsynaptic calcium increases are known to be required in the induction of long-term synaptic plasticity (34), we then tested whether iLTD IGFI $_{\text {induction required }}$ cytosolic calcium elevation in the recorded neuron. We used the same experimental approach described above, but now including the $\mathrm{Ca}^{2+}$ chelator BAPTA $(40 \mathrm{mM})$ in the patch pipette to prevent neuronal calcium elevations. BAPTA loading of the postsynaptic neuron abolished the calcium increases evoked by neuronal depolarization 
(Supplementary Figure 1). However, a similar iLTD IGFI $_{\text {was induced in both control }}$ and neuron BAPTA-loaded conditions (from $100.08 \pm 0.60$ to $68.67 \pm 6.76 \%$ of IPSC peak amplitude, before and after IGF-I. $\mathrm{N}=7, \mathrm{P}<0.01$; Figure 1C). Taken together, these data demonstrate that IGF-I induces LTD of IPSCs without requiring cytosolic calcium elevations in the postsynaptic neuron. To test a possible presynaptic origin of the effect of IGF-I, we recorded the IPSCs evoked by paired-pulse stimulation $(50 \mathrm{~ms}$ delay), and analyzed changes in paired-pulse responses (PPRs). PPRs were increased during IGF-I-mediated LTD of the IPSCs (from $100.00 \pm 3.23$ to $120.37 \pm 5.33 \%$ of IPSC paired-pulse responses, before and after IGF-I. $\mathrm{N}=7, \mathrm{P}<0.01$; Figure 1D, ACSF) indicating that they were mediated by a presynaptic mechanism.

Astrocytes are emerging as important cells involved in the regulation of synaptic transmission and plasticity(35). Therefore, we next determined whether iLTD IGFI requires cytosolic calcium elevations in astrocytes. First, we tested whether astrocytes responded to IGF-I blocking glutamatergic, GABAergic, cholinergic, purinergic and dopaminergic receptors. We used a cocktail containing CNQX and D-AP5 (20 $\mu \mathrm{M}$ and $50 \mu \mathrm{M}$; for AMPA/kainite and NMDA glutamate receptors respectively), MPEP and LY367385 (50 $\mu \mathrm{M}$ and $100 \mu \mathrm{M}$; for mGluR5 and mGluR1 respectively), picrotoxin and CGP (50 $\mu \mathrm{M}$ and $1 \mu \mathrm{M}$; for $\mathrm{GABA}_{\mathrm{A}} \mathrm{Rs}$ and $\mathrm{GABA}_{\mathrm{B}} \mathrm{Rs}$ respectively), atropine (50 $\mu \mathrm{M}$; for muscarinic cholinergic receptors), CPT ( $2 \mu \mathrm{M}$; for A1 adenosine receptors), suramin (100 $\mu \mathrm{M}$; for $\mathrm{P} 2$ purinergic receptors) and flupenthixol $(30 \mu \mathrm{M}$; for $\mathrm{D} 1 / \mathrm{D} 2$ dopaminergic receptors). In addition, TTX $(1 \mu \mathrm{M})$ was also added to the cocktail to prevent action potential-mediated neurotransmitter release. Application of IGF-I induced an increase in the frequency of astrocyte calcium elevations (from $0.75 \pm 0.08$ to $1.22 \pm 0.10 \mathrm{~min}^{-1}$ before and during IGF-I. $\mathrm{N}=46$ astrocytes, $\mathrm{P}<0.01$; Figure $3 \mathrm{C}$, ACSF. From $1.60 \pm 0.03$ to $2.93 \pm 0.05 \mathrm{~min}^{-1}$ before and during IGF-I. $\mathrm{N}=133$ 
processes, $\mathrm{P}<0.01$; Figure 1E, F), that was absent under NVP (from $0.89 \pm 0.14$ to $0.97 \pm 0.14 \mathrm{~min}^{-1}$ before and during IGF-I. $\mathrm{N}=81$ astrocytes, $\mathrm{P}=0.73$; Figure 1G, NVP). Then, we tested whether the IGFI-induced enhancement of astrocyte calcium signal contributed to the $\mathrm{iLTD}_{\mathrm{IGFI}}$. We prevented the $\mathrm{Ca}^{2+}$ signal selectively in astrocytes, by recording a cortical astrocyte with a patch pipette containing $40 \mathrm{mM}$ BAPTA. Since cortical astrocytes are gap-junction connected, BAPTA injected in a single astrocyte can diffuse throughout a large extension of the gap junction-coupled astrocytic network (30)(36)(37). After BAPTA-loading of the astrocytic network, IGF-I failed to modulate the IPSCs (from $99.79 \pm 0.62$ to $92.75 \pm 6.20 \%$ of IPSC peak amplitude, before and after IGF-I. N = 6, P = 0.31; Figure 1H) or the PPR (from 100.00 \pm 3.86 to $98.01 \pm 2.48 \%$ of IPSC paired-pulse responses, before and after IGF-I. $\mathrm{N}=6$, $\mathrm{P}=0.67$; Figure 1I). Taken together, these data suggest that cytosolic $\mathrm{Ca}^{2+}$ increases in astrocytes, but not in the recorded PN (see above results), are essential for the induction of iLTD

\section{iLTD $_{\text {IGFI }}$ requires IGF-IR activation in astrocytes.}

Above experiments show that iLTD $_{\text {IGFI }}$ requires astrocyte calcium elevations. However, astrocyte stimulation by IGF-I could occur directly through either activation of astrocytic receptors, or indirectly through activation of neuronal receptors that trigger an indirect signaling pathway. To discriminate between these two possibilities, we deleted IGF-IR specifically in astrocytes using a combined viral and genetic approach. Mice with floxed IGF-IR gene $\left(\mathrm{IGF}_{\mathrm{IR}}^{\mathrm{f} / \mathrm{f}}\right.$ mice) were injected in the barrel cortex with the virus AAV8-GFAP-Cre-mCherry (or AAV8-GFAP-mCherry as a control) that included the Cre-recombinase under the astroglial promoter GFAP, and mCherry as a reporter (Figure 2A). To delete IGF-IRs selectively in cortical astrocytes, mice were injected in the barrel cortex with $500 \mathrm{nl}$ of the viral vector AAV8-GFAP-Cre-mCherry (or AAV8- 
GFAP-mCherry as a control, i.e., lacking the Cre recombinase). Immunohistochemistry analysis confirmed the selective expression of the virus in cortical astrocytes. Furthermore, in IGF-IR ${ }^{\mathrm{f} / \mathrm{f}}$ mice injected with AAV8-GFAP-Cre-mCherry, mCherry expression was largely reduced and confined to the soma (Figure 2B, mCherry, IGF$\mathbf{I R}^{-/-}$) compared to the higher and more spread signal in control littermates (Figure 2B, mCherry, IGF-IR ${ }^{\mathrm{WT}}$ ).

As expected, in IGF-IR ${ }^{\mathrm{WT}}$, IGF-I elevates astrocyte calcium levels (Figure 1E, F) inducing the iLTD $_{\text {IGFI }}$ and increasing the PPR (from $99.89 \pm 0.80$ to $74.74 \pm 4.97 \%$ of IPSC peak amplitude before and after IGF-I. $\mathrm{N}=5, \mathrm{P}<0.01$; Figure 2C, yellow circles; PPR: from $100.00 \pm 2.64$ to $120.92 \pm 1.31 \%$ of IPSC paired-pulse responses, before and after IGF-I. N = 5, P $<0.001$; Figure 2D, IGF-IR ${ }^{\mathrm{WT}}$ ). In contrast, in IGF-IR ${ }^{-}$ I- mice, IGF-I did not modify the frequency of calcium elevations in astrocytes (from $1.23 \pm 0.02$ to $1.04 \pm 0.004 \mathrm{~min}^{-1}$ before and during IGF-I. $\mathrm{N}=67$ processes, $\mathrm{P}=0.28$

Figure 2E, F) and did not alter the IPSC amplitude and PPR (from $100.27 \pm 1.55$ to $107.16 \pm 5.62 \%$ of IPSC peak amplitude before and after IGF-I. $\mathrm{N}=5, \mathrm{P}=0.29$; Figure 2C, green circles; PPR: from $100.00 \pm 5.36$ to $102.92 \pm 5.05 \%$ of IPSC pairedpulse responses, before and after IGF-I. $\mathrm{N}=5, \mathrm{P}=0.70$; Figure 2D, IGF-IR ${ }^{-/}$). These results demonstrate that IGF-IR in astrocytes are necessary for the induction of iLTD IGFI.

\section{iLTD $D_{\text {IGFI }}$ requires $A_{2 A}$ adenosine receptor activation}

Astrocytic activation may stimulate the release of ATP, which, after being converted to adenosine, may regulate synaptic transmission(38)'(35) in the hippocampus, cortex and striatum(39)'(40)'(41). Therefore, we tested whether astrocytic ATP/Adenosine was responsible for the $\mathrm{iLTD}_{\mathrm{IGFI}}$. The $\mathrm{iLTD}_{\mathrm{IGFI}}$ was abolished by the antagonist of adenosine 
$\mathrm{A}_{2 \mathrm{~A}}$ receptors $\mathrm{SCH} 58261(100 \mathrm{nM}$; from $100.02 \pm 0.63$ to $94.98 \pm 2.43 \%$ of IPSC peak amplitude, before and after IGF-I. $\mathrm{N}=8, \mathrm{P}=0.07$; Figure 3A, purple circles), but not by the antagonist of adenosine A1 receptors, CPT (5 $\mu \mathrm{M}$; from $98.72 \pm 1.75$ to $55.74 \pm$ $7.08 \%$ of IPSC peak amplitude, before and after IGF-I. N = 7; P < 0.001; Figure 3A, blue circles). Moreover, the increase in PPR induced by IGF-I was preserved in the presence of CPT but absent in SCH 58261 (from $100.00 \pm 5.90$ to $118.42 \pm 4.95 \%$ of IPSC paired-pulse responses in the presence of CPT, before and after IGF-I. N = 7, P < 0.05 . From $100.00 \pm 2.96$ to $99.76 \pm 1.85 \%$ of IPSC paired-pulse responses in the presence of $\mathrm{SCH}$, before and after IGF-I. $\mathrm{N}=8, \mathrm{P}=0.94$; Figure 3B). To test whether adenosine-receptor activation occurs downstream of astrocytic calcium activity, we analyzed the effects of $\mathrm{A}_{2 \mathrm{~A}}$ and $\mathrm{A}_{1}$ receptor antagonists on astrocytic calcium signals. We observed that IGF-I evoked an increase in calcium event frequency in the presence of $\mathrm{SCH}$ (from $0.67 \pm 0.12$ to $1.40 \pm 0.17 \mathrm{~min}^{-1}$ before and during IGF-I. $\mathrm{N}=48$ astrocytes, $\mathrm{P}<0.01$; Figure 3C, SCH), and CPT (from $0.59 \pm 0.10$ to $1.20 \pm 0.13$ min-1 before and during IGF-I. $\mathrm{N}=72$ astrocytes, $\mathrm{P}<0.01$; Figure 3C, CPT). Taken together, these results indicate that IGF-I induces an increase in calcium levels in astrocytes, which leads to the activation of $\mathrm{A}_{2 \mathrm{~A}}$ receptors, thus inducing iLTDIGFI.

\section{IGF-I induces ATP release from astrocytes depending on IGF-IR.}

We next tested whether IGF-I was capable of stimulate the release of ATP in astrocytes. We used the ATP Assay Kit (see Mat and Methods) to monitor ATP levels in cultured astrocytes before and after $1 \mathrm{~h}$ of treatment with IGF-I (10nM). We found that IGF-I elevated the extracellular levels of ATP (from $0.1 \pm 0.02$ to $1.1 \pm 0.04 \mathrm{nmol} / \mu \mathrm{g}$ of protein before and during IGF-I, $\mathrm{N}=6$; $\mathrm{P}<0.001$; Figure 3D), an effect that was prevented when cultures where simultaneously treated with NVP $(0.25 \pm 0.05 \mathrm{nmol} / \mu \mathrm{g}$ of protein, during IGF-I, $\mathrm{N}=6 ; \mathrm{P}<0.001$; Figure 3D). The IGF-I-induced release of 
ATP was absent when astrocyte calcium signaling was prevented by treating cultures with BAPTA-AM $(0.45 \pm 0.04 \mathrm{nmol} / \mu \mathrm{g}$ of protein during IGF-I, $\mathrm{N}=6 ; \mathrm{P}<0.01$;

Figure 3D). Moreover, it was also abolished by thapsigargin, which inhibits the calcium ATPase and prevents calcium mobilization from internal stores $(0.45 \pm 0.03 \mathrm{nmol} / \mu \mathrm{g}$ of protein during IGF-I, $\mathrm{N}=6 ; \mathrm{P}<0.001$; Figure 3D). Moreover, the release of ATP was absent when astrocytes were obtained from mice lacking IGF-IR in astrocytes (from $0.08 \pm 0.005$ to $0.3 \pm 0.01 \mathrm{nmol} / \mu \mathrm{g}$ of protein, before and during IGF-I. $\mathrm{N}=6 ; \mathrm{P}<0.01$;

Figure 3E). Finally, the release of ATP was also absent in the $\mathrm{IP}_{3} \mathrm{R} 2$-null mice (from $0.18 \pm 0.008$ to $0.22 \pm 0.009 \mathrm{nmol} / \mu \mathrm{g}$ of protein, before and during IGF-I. $\mathrm{N}=4 ; \mathrm{P}<$ 0.01; Figure 3E), a mouse in which G-protein-mediated calcium elevation is impaired in astrocytes (42)'(40). Taken together, these data suggest that IGF-I, acting through the IGF-IR in astrocytes, stimulates the calcium-dependent release of ATP.

Astrocytic activation stimulates the release of glutamate in the hippocampus, cortex and striatum (36)(41)(40)'. However, iLTD IGFI was unaffected by treatment with antagonists of group I metabotropic glutamate receptors (mGluRs) MPEP (50 $\mu \mathrm{M})$ and LY367385 (100 $\mu \mathrm{M}$; Supplementary Figure 2 ), (from $98.89 \pm 0.90$ to $60.78 \pm 7.39 \%$ IPSC peak amplitude, before and after IGF-I. $\mathrm{N}=6$; $\mathrm{P}<0.01$; Figure 4A) and the increase in the PPR induced by IGF-I was preserved (from $100.00 \pm 4.06$ to $120.52 \pm 7.66 \%$ of IPSC paired-pulse responses, before and after IGF-I. $\mathrm{N}=6, \mathrm{P}<0.05$; Figure 4B). Moreover, we observed that IGF-I evoked an increase in calcium event frequency in the presence of MPEP + LY367385 (from $0.51 \pm 0.12$ to $1.07 \pm 0.14 \mathrm{~min}^{-1}$ before and during IGF-I. $\mathrm{N}=44$ astrocytes, $\mathrm{P}<0.05$; Figure 4E, F, MPEP + LY367385). Although astrocytes are able to release glutamate, these data rule out the requirement of mGLUR activation in the induction of iLTD IGFI. $_{\text {. }}$ 


\section{iLTD $_{\text {IGFI }}$ is absent in the $\mathrm{IP}_{\mathbf{3}} \mathrm{R} 2$-null transgenic mice.}

Because cytosolic calcium elevation and ATP release from astrocytes are required for iLTD $_{\text {IGF1 }}$, we expected iLTD IGFI $_{\text {to }}$ be absent in $\mathrm{IP}_{3} \mathrm{R} 2$-null mice (Supplementary

Figure 3). The frequency of somatic calcium elevations in astrocytes of $\mathrm{IP}_{3} \mathrm{R} 2^{-/-}$mice was not altered during IGF-I application (from $0.001 \pm 0.001$ to $0.001 \pm 0.0009 \mathrm{~min}-1$ before and during IGF-I. $\mathrm{N}=61$ astrocytes, $\mathrm{P}=1$; Figure $4 \mathbf{E}, \mathbf{F}, \mathrm{IP}_{3} \mathrm{R} 2^{-/}$), and not only iLTD $_{\text {IGFI. }}$ was abolished, but a LTP of the IPSCs was induced (from $100.55 \pm 0.64$ to 167.11 $\pm 23.79 \%$ IPSC peak amplitude, before and after IGF-I. $\mathrm{N}=6, \mathrm{P}<0.05$; Figure 4C; PPR: from $100.00 \pm 3.72$ to $100.39 \pm 4.30 \%$ of IPSC paired-pulse responses, before and after IGF-I. $\mathrm{N}=6, \mathrm{P}=0.94$; Figure 4D). These results further support the idea that iLTD $_{\text {IGFI }}$ depends on IGF-IR activation in astrocytes.

The performance of a whisker discrimination task is impaired in the astrocytespecific IGF-IR ${ }^{-/-}$mice.

Finally, we tested whether the activation of IGF-IR on astrocytes was involved in the performance of a barrel cortex dependent discrimination task. We used a test based on the ability of the mice to discriminate different textures in the arms of a Y maze (Figure 5A). We compare the ability to perform this task on the astrocyte-specific IGF-IR ${ }^{-/-}$ mice (Supplementary Figure 4A) with their control littermates. While no differences were seen between IGF-IR ${ }^{-/-}$mice and control littermates in the number of visits to the arms (Figure 5B), indicating normal deambulatory activity, IGF-IR ${ }^{-/-}$mice spent less time examining the arm with the novel texture $(\mathrm{N}=11 ; \mathrm{P}=0,0336$; Figure $\mathbf{5 C}$ left), indicating impaired texture discrimination (Figure 5C right). Conversely, whisker perception in IGF-IR ${ }^{-/-}$mice was preserved, as indicated by normal performance in the gap-crossing test (Supplementary Figure 4B). In addition, working memory was also 
normal in $\mathrm{IGF}_{\mathrm{IR}}{ }^{-/-}$mice, as indicated by preserved performance in the $\mathrm{Y}$ maze alternation test (Supplementary Figure 4C). Taken together these results indicate that IGF-IR on astrocytes is involved in the texture discrimination in mice.

\section{DISCUSSION}

The operation of cortical circuits depends on a fast time course of inhibitory signaling in interneurons, whereas modulation of synaptic inhibition plays a crucial role in the induction of cortical plasticity. Our results show that IGF-I can induce a long lasting

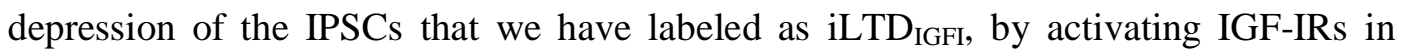
astrocytes. The latter induces a calcium-dependent release of ATP/Ado, and iLTD IGFI depends on the activation of $\mathrm{A}_{2 \mathrm{~A}}$ adenosine receptors (see mechanistic cartoon). These presynaptic adenosine receptors would induce a decrease in the probability of GABA

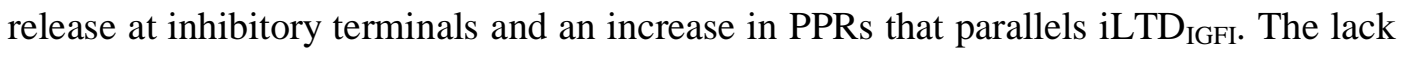
of $\mathrm{iLTD}_{\mathrm{IGFI}}$ in $\mathrm{IP}_{3} \mathrm{R}^{-/-}$mice and in mice in which IGF-IR has been selectively ablated in astrocytes, demonstrates that both IGF-IR activation in astrocytes and somatic cytosolic calcium elevations are crucial in the induction of this novel form of long lasting down regulation of cortical synaptic inhibition. Although $\mathrm{IP}_{3} \mathrm{R} 2^{-/-}$mice present residual $\mathrm{Ca}^{2+}$ events that might occur in fine processes(43), it seems that the existence of those events would not be sufficient to induce iLTD IGFI. Quite the opposite, an intriguing LTP of the IPSCs is revealed. Thus, these data suggest that although astrocyte-synaptic interactions

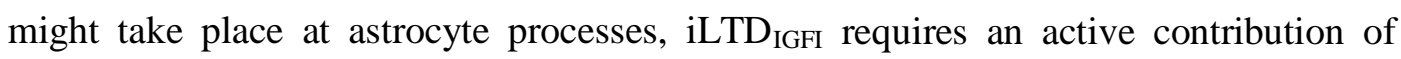
astrocytic somatic $\mathrm{Ca}^{2+}$ signaling. Importantly, $\mathrm{IP}_{3} \mathrm{R} 2^{-/-}$mice have recently been reported to show impaired LTD and memory deficits (44).

IGF-I elicits a long-lasting depression of GABA release by cerebellar Purkinje cells in response to glutamate, indicating that IGF-I may act as a modulator of glutamatergic transmission in the adult rat olivo-cerebellar system (10)(45). Also, IGF-I has been 
shown to modulate GABAergic transmission in the olfactory bulb (13). However, an IGF-I mediated long lasting depression of fast GABAergic synaptic transmission in the neocortex has not been described before. Here we demonstrate that IGF-I induces the release of ATP from cortical astrocytes, that in turn is converted to adenosine to induce long-lasting depression of GABA release. Although IGF-IRs may be present in inhibitory GABAergic terminals, there are no clear data showing a direct action of IGFI acting on presynaptic IGF-IRs. The only evidence suggesting this mode of action is seen in the hippocampus where IGF-I, acting possibly via GABAergic neurons, can induce the release of GABA to regulate endogenous ACh release (11). At any rate, our observations contribute to the notion that IGF-I can modulate both stimulatory and inhibitory synaptic activity throughout the CNS.

In rodent astrocytes, IGF-I signaling is important for glucose uptake, regulation of glutamate transport and protection against oxidative stress in the brain (46)(47)(48). Indeed, loss of IGF-IR has been associated with increased GLUT1 activity and, consequently, increased glucose uptake (25). Although there is evidence showing that insulin signaling in astrocytes mediates tyrosine phosphorylation of Munc18cand syntaxin-4-dependent ATP exocytosis, which in turn modulates presynaptic dopamine release (49), we have not found previous evidence for an stimulatory action of IGF-I on ATP release by astrocytes. In this regard, it has been previously shown that metabotropic Protease-activated receptor 1 (PAR-1) induces exocytosis of ATP from cortical astrocytes, which leads to a short term downregulation of inhibitory synaptic currents in layer $2 / 3$ pyramidal neurons (33). In contrast with the presynaptic iLTD described herein, this short term modulation is mediated by a postsynaptic mechanism in which $\mathrm{Ca}^{2+}$-entry through the neuronal $\mathrm{P} 2 \mathrm{X}$ purine receptor leads to a phosphorylation-dependent down-regulation of $\mathrm{GABA}_{\mathrm{A}}$ receptors. Therefore, astrocytes 
can down- or up-regulate inhibitory synaptic transmission by a calcium-dependent release of ATP depending on whether IGF-IR or PAR1R are activated, respectively.

Astrocytes have been shown to respond to both glutamate and GABA $(28)(50)(51)(36)(52)$, which allows them to sense the activity of excitatory and inhibitory neurons. In response to these neurotransmitters they can release both glutamate and ATP/Ado (53)(35)(54)(55)(56). Indeed, hippocampal interneuron activity leads to $\mathrm{GABA}_{\mathrm{B}} \mathrm{R}$-mediated release of glutamate from astrocytes that potentiates both inhibitory (28), and excitatory (29) synaptic transmission. In addition to glutamate, hippocampal astrocytes may also release ATP, which is converted to adenosine that depress $(57)(30)(31)(32)$ or potentiates excitatory synaptic transmission (38). Moreover, ATP released by astrocytes can depress excitatory synapses from basolateral amygdala and enhance inhibitory synapses from the lateral subdivision of the central amygdala via the activation of $\mathrm{A}_{1}$ and $\mathrm{A}_{2 \mathrm{~A}}$ adenosine receptors, respectively (58). Furthermore, cortical astrocytes have been shown to induce a short-term depression of inhibitory synaptic currents (33). However, to our knowledge, we present the first evidence showing that IGF-IR activation in astrocytes can induce a long lasting depression of inhibitory cortical synaptic transmission through the release of ATP/Ado via a presynaptic mechanism.

At the circuit level, interneurons control the flow of information and synchronization in the cerebral cortex. Synaptic inhibition is involved in the emergence of fast brain rhythms (59), and in the induction of synaptic plasticity (60), that jointly contribute to cognitive functions. Indeed, disruption of astrocytic vesicular release has been found crucial for gamma oscillatory hippocampal activity with significant impact in recognition memory tasks (61). Our results demonstrate that IGF-I receptor on astrocytes improves the performance of the texture discrimination in mice, suggesting 
that the iLTD $_{\text {IGFI }}$ could be essential in this barrel cortex dependent task. The release of ATP/Ado from astrocytes and the $\mathrm{iLTD}_{\mathrm{IGFI}}$ described here could play a relevant role in this cognitive function by controlling brain rhythms and favoring the induction of Hebbian synaptic plasticity. Decreased synaptic inhibition would facilitate the backpropagation of action potentials into the dendrites and the induction of spike timingdependent plasticity. In addition, by changing the ratio between synaptic excitation and inhibition, neuronal membranes can rapidly reach the threshold for action-potential generation, and enhanced cortical activity is expected when cortical levels of IGF-I increase. Indeed, this increase in cortical activity would activate neurotrophic coupling mechanism of entrance of IGF-I from the plasma into the brain (2).

In summary, the present findings reveal novel mechanisms and functional consequences of IGF-I signaling in the cortex. It induces the long-term depression of GABAergic inhibition (iLTD $\mathrm{IGFI}_{\text {) }}$ and regulates the behavioral performance in the barrel cortexrelated texture discrimination tasks, though activation of cortical astrocytes.

\section{METHODS}

Materials: 2-(2-Furanyl)-7-(2-phenylethyl)-7H-pyrazolo[4,3-e][1,2,4] triazolo [1,5-c] pyrimidin-5-amine (SCH58261 $(\mathrm{SCH})$ ), 8-Cyclopentyltheophylline (CPT) and thapsigargin were purchased from Tocris. NVP AEW541 (NVP) was purchased from Cayman. Recombinant Human IGF-I (IGF-I) was from Peprotech. BAPTA-K4 was from Santa Cruz Byotechnology. Fluo-4-AM was purchased from Invitrogen and ATP Assay Kit was from Abcam. The rest of drugs were purchased from Sigma-Aldrich.

Ethics statement and animals. All animal procedures were approved by the Ethical Committee of the Universidad Autónoma of Madrid, and Cajal Institute and are in accordance with Spanish (R.D. 1201/2005) and European Community Directives 
(86/609/EEC and 2003/65/EC), which promote animal welfare. Male C57BL/6J or transgenic mice were housed under a 12-h/12-h light/dark cycle with up to five animals per cage and were used for slice electrophysiology. Transgenic mice with a deletion of IGF-IR in astrocytes (GFAP-IGF-IR ${ }^{-/-}$mice) were obtained by injecting IGF-IR ${ }^{\mathrm{f} / \mathrm{f}}$ mice (B6, 129 background; Jackson Labs) with AAV8-GFAP-mCherry (UMN vector core) or AAV8-GFAP-mCherry-CRE viral vectors (UNC vector core). For a subset of experiments, slices were obtained from male $\mathrm{IP}_{3} \mathrm{R} 2^{-/-}$mice generously donated by Gertrudis Perea (Cajal Institute).

Slice preparation. Wild type and $\mathrm{IP}_{3} \mathrm{R} 2^{-/-}$mice (12-18 days old), as well as GFAP-IGF-IR ${ }^{-/-}$mice and their controls (12-20 weeks of age) were sacrificed, and brains submerged in cold $\left(4^{\circ} \mathrm{C}\right)$ cutting solution containing (in $\left.\mathrm{mM}\right): 189.0$ sucrose, 10.0 glucose, 26.0 $\mathrm{NaHCO}_{3}, 3.0 \mathrm{KCl}, 5.0 \mathrm{Mg}_{2} \mathrm{SO}_{4}, 0.1 \mathrm{CaCl}_{2}, 1.25 \mathrm{NaH}_{2} \mathrm{PO}_{4} .2 \mathrm{H}_{2} \mathrm{O}$. Coronal slices $(350 \mu \mathrm{m}$ thick) were cut with a Vibratome (Leica VT 1200S), and incubated (>1h, $25-27^{\circ} \mathrm{C}$ ) in artificial cerebrospinal fluid (ACSF) containing (in $\mathrm{mM}$ ): $124.00 \mathrm{NaCl}$, 2.69 KCl, $1.25 \mathrm{KH}_{2} \mathrm{PO}_{4}, 2.00 \mathrm{Mg}_{2} \mathrm{SO}_{4}, 26.00 \mathrm{NaHCO}_{3}, 2.00 \mathrm{CaCl}_{2}$, and 10.00 glucose). $\mathrm{pH}$ was stabilized at 7.3 with a $95 \% \mathrm{O}_{2}, 5 \% \mathrm{CO}_{2}$ mixture. Slices were transferred to a 2 $\mathrm{ml}$ chamber fixed to an upright microscope stage (BX51WI; Olympus, Tokyo, Japan) equipped with infrared differential interference contrast video (DIC) microscopy and superfused at room temperature with $95 \% \mathrm{O}_{2}, 5 \% \mathrm{CO}_{2}$-bubbled ACSF ( $\left.2 \mathrm{ml} / \mathrm{min}\right)$.

Electrophysiological recordings. Patch-clamp recordings from layer 2/3 pyramidal neurons of the barrel cortex were performed in whole-cell voltage-clamp configurations with patch pipettes (4-8 M $\Omega$ ) filled with an internal solution that contained (in mM): $135 \mathrm{KMeSO}_{4}, 10 \mathrm{KCl}, 10 \mathrm{HEPES}-\mathrm{K}, 5 \mathrm{NaCl}, 2.5 \mathrm{ATP}-\mathrm{Mg}^{+2}$, and 0.3 GTP-Na ${ }^{+}, \mathrm{pH}$ 7.3. In some experiments, a BAPTA-based intracellular solution was used (in mM): 40 BAPTA-K 4 , 2 ATP-Na ${ }^{2+}, 10$ mM HEPES, $1 \mathrm{MgCl}_{2}$ and $8 \mathrm{NaCl}, \mathrm{pH}$ 
7.3 Recordings were performed using a Cornerstone PC-ONE amplifier (DAGAN, Minneapolis, MN). Pipettes were placed with a mechanical micromanipulator (Narishige, Tokyo, Japan). The holding potential was adjusted in a range from -70 to $80 \mathrm{mV}$, and series resistance was compensated to $\approx 80 \%$. Layer $2 / 3$ pyramidal neurons located over the barrels (layer 4) were accepted only when the seal resistance was $>1$ $\mathrm{G} \Omega$ and the series resistance $(10-20 \mathrm{M} \Omega)$ did not change (>20\%) during the experiment. Data were low-pass filtered at $3.0 \mathrm{kHz}$ and sampled at $10.0 \mathrm{kHz}$, through a Digidata 1550B (Molecular Devices, Sunnyvale, CA).

Synaptic stimulation. Inhibitory synaptic currents (IPSCs) were isolated in the presence of AMPAR and NMDAR antagonists $(20 \mu \mathrm{M}$ CNQX and $50 \mu \mathrm{M}$ D-AP5, respectively). IPSCs were evoked with a bipolar stimulation electrode pulled from theta

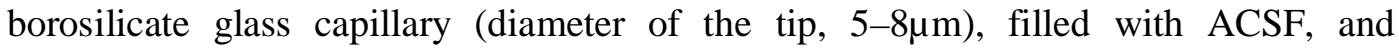
connected to a Grass S88 stimulator and a stimulus isolation unit (Quincy, USA digital stimulator) through chloride-silver electrodes. The stimulating electrodes were placed at layer 4 of the barrel cortex near the tip $(\sim 100-150 \mu \mathrm{m})$ of the recording pipette. Paired pulses $(200-\mu$ s duration and $50 \mathrm{~ms}$-interval) were continuously delivered at $0.33 \mathrm{~Hz}$. After recording 5 minutes of stable baseline of IPSCs, IGF-I was added to the bath during 35 minutes. After that, IGF-I was washed for at least 10 minutes and the amplitude of the IPSCs after IGF-I washout was continuously checked. The pre- or postsynaptic origin of the observed regulation of synaptic currents was tested by estimating changes in the paired pulse ratio (PPR) of the IPSCs (62)(63)(64). We calculated the PPR index (R2/R1), where R1 and R2 are the peak amplitudes of the first and second IPSC, respectively.

Stereotaxic surgery and virus delivery. Animals between 6-10 weeks' old were anesthetized with ketamine $(100 \mathrm{mg} / \mathrm{kg}) / x y l a z i n e ~(10 \mathrm{mg} / \mathrm{kg})$ mix. To delete IGF-IRs 
selectively in cortical astrocytes, IGF-IR ${ }^{\mathrm{f} / \mathrm{f}}$ mice were injected in the barrel cortex with $500 \mathrm{nl}$ of the viral vector AAV8-GFAP-mCherry-CRE (or AAV8-GFAP-mCherry as a control). To monitor astrocyte calcium levels, mice were injected with AAV5GFAPABC1D-cytoGCaMP6f-SV40 (Penn Vector Core). Injections were made at layer 2/3 of barrel cortex with a Hamilton syringe attached to a 29-gauge needle at a rate of $0.5 \mu \mathrm{l} / \mathrm{min}$. Coordinates used to reach the area were: anterior-posterior: $-1.0 \mathrm{~mm}$; medial-lateral: $+/-3.50 \mathrm{~mm}$; dorsal-ventral: $-0.15 \mathrm{~mm}$. Three weeks after the injection, successful delivery was confirmed by the location of the virus based on mCherry expression.

$\boldsymbol{C a}^{2+}$ imaging. In GFAP-IGF- $\mathrm{IR}^{-{ }^{-}}$mice and their controls, $\mathrm{Ca}^{2+}$ levels in astrocyte soma and processes were obtained by two-photon microscopy (Leica DM6000 CFS upright multiphoton microscope with TCS SP5 MP laser) using the GCaMP6f viral vector targeted to astrocytes. In some experiments, somatic $\mathrm{Ca}^{2+}$ levels were obtained by using epifluorescence microscopy and the $\mathrm{Ca}^{2+}$ indicator Fluor-4-AM $(5 \mu \mathrm{M}$ in $0.01 \%$ of pluronic, $30-45 \mathrm{~min}$ incubation at room temperature). Loaded cells were illuminated every $100 \mathrm{~ms}$ at $490 \mathrm{~nm}$ with a monochromator (Polychrome IV; TILL Photonics), and successive images were obtained at $1 \mathrm{~Hz}$ with a cooled monochrome CCD camera (Hammamatsu, Japan) attached to the Olympus microscope that was equipped with a filter cube (Chroma Technology). Camera control and synchronization for the epifluorescence were made by ImagingWorkbench software (INDECBioSystems) and for two-photon imaging by the Leica LAS software.

Astrocyte cultures and ATP release. Pure astroglial cultures were prepared as described(65). Postnatal (day 0-2) brains from C57BL/6J (WT) and constitutively GFAP IGF-IR ${ }^{-1-}$ mice(25) were removed and immersed in ice-cold Earle's balanced salt solution (ThermoFisher, Waltham, MA USA). Cortices were dissected and 
mechanically dissociated. The resulting cell suspension was centrifuged and plated in DMEM/F-12 (ThermoFisher) with 10\% fetal bovine serum (FBS, ThermoFisher) and $100 \mathrm{mg} / \mathrm{ml}$ of antibiotic-antimycotic solution (Sigma, St. Louis, MO, USA). Cell cultures were maintained in an incubator at $37{ }^{\circ} \mathrm{C}$ in $95 \%$ humidity with $5 \% \mathrm{CO} 2$. Pure astrocytes monolayer cultures were replated at $2.5 \times 10^{5}$ cells/well in DMEM/F-12 with 10\% FBS medium. After two days, medium was replaced by DMEM/F-12 during 3 hours followed by one-hour treatment with 10 nM IGF-I (PreproTech, Rocky Hill, NJ, USA) or one-hour treatment with inhibitors: $400 \mathrm{nM}$ NVP-AEW541 (IGF-I receptor antagonist, Cayman, Ann Arbor, MI, USA), $10 \mu \mathrm{M}$ BAPTA-AM (intercellular Ca2+ chelator, Sigma) or $1 \mu \mathrm{M}$ Thapsigargin (endoplasmic reticular Ca2+-ATPase inhibitor, Tocris, Bristol, UK) followed by one-hour stimulation with $10 \mathrm{nM}$ IGF-I.

The amount of ATP released into the medium was measured with an ATP Assay Kit (Fluorometric, ab83355; Abcam, Cambridge, UK) according to the manufacturer's instructions. Firstly, cells were washed with cold phosphate-buffered saline and resuspended in $100 \mu \mathrm{l}$ of ATP assay buffer. Then, the cells were quickly homogenized by pipetting up and down, and centrifuged for $2 \mathrm{~min}$ at $4^{\circ} \mathrm{C}(18000 \mathrm{~g})$ to remove any insoluble material. Thereafter, the supernatant was collected and transferred to a clean tube and kept on ice. ATP assay buffer $(400 \mu \mathrm{L})$ and $100 \mu \mathrm{L}$ of ice cold $4 \mathrm{M}$ perchloric acid were added to the homogenate to deproteinate the samples. Homogenates were vortexed briefly and incubated on ice for $5 \mathrm{~min}$, centrifuged at $18000 \mathrm{~g}$ for $2 \mathrm{~min}$ at $4^{\circ} \mathrm{C}$, and the supernatant transferred to a fresh tube. The supernatant volume was measured and an equal volume of ice cold $2 \mathrm{M} \mathrm{KOH}$ was added. Finally, the homogenate was centrifuged at $18000 \mathrm{~g}$ for $15 \mathrm{~min}$ at $4^{\circ} \mathrm{C}$ and the supernatant collected. ATP reaction mix $(50 \mu \mathrm{L})$ and $50 \mu \mathrm{L}$ of sample were added to each well and incubated at $24{ }^{\circ} \mathrm{C}$ for $30 \mathrm{~min}$, protected from light. Samples were measured on a 
FLUOstar microplate reader (BMG LabTech, Ortenberg, Germany) at 535/587 nm. Each sample was run in duplicate. The concentrations of ATP released from astrocyte primary cultures were obtained from standard curves and normalized to the total amount of protein.

Behavioral experiments. Adult male and female control (C57BL/6JolaHsd; 6-12 months old; $28-35 \mathrm{~g}$ ), and transgenic mice were used in these studies. Transgenic mice with tamoxifen-regulated deletion of IGF-IR in astrocytes (IGF-IR ${ }^{-/-}$mice) were obtained by crossing IGF-IRf/f mice (B6, 129 background (IGF-IRflox/flox mice; Jackson Labs; stock number: 012251) with CreERT2.GFAP mice (C57B\&/6xSJL/J mix background; Jackson Labs, stock number: 012849, see (66) for further details). In these animals, IGF-IR activity is knocked down after administration of tamoxifen, as described elsewhere (67). Tamoxifen was injected for 5 consecutive days intraperitoneally (75 mg/kg, Sigma) at the age of $1 \mathrm{month}$, and animals were used at 2-7 months old. Controls used were siblings treated with the vehicle for tamoxifen injections (corn oil). Using the tdTomato/eGFP reporter mouse to detect Cre-mediated deletion in response to tamoxifen administration in CreERT2.GFAP mice, we previously documented that it was restricted to astrocytes (68). Multiplex PCR for mouse genotyping included a common forward primer (P3, 5'-CTG TTT ACC ATG GCT GAG ATC TC-3') and two reverse primers specific for the wild-type (P4, 5'-CCA AGG ATA TAA CAG ACA CCA TT-3') and mutant (P2, 5'-CGC CTC CCC TAC CCG GTA GAA TTC-3') alleles. GFAP-T-IGF-IR mice show lower levels of IGF-IR in brain after tamoxifen injection. Mice were housed in standard cages $(48 \times 26 \mathrm{~cm} 2)$ with 4 - 5 animals per cage, kept in a room with controlled temperature $\left(22^{\circ} \mathrm{C}\right)$ under a 12-12h light-dark cycle, and fed with a pellet rodent diet and water ad libitum. All experimental protocols were performed during the light cycle between 14 pm - 18 pm. 
Animal procedures followed European guidelines (2010/63/EU) and were approved by the local Bioethics Committee (Madrid Government). qPCR: Total RNA isolation from brain tissue was carried out with Trizol. One mg of RNA was reverse transcribed using High Capacity cDNA Reverse Transcription Kit (ThermoFisher Scientific, USA) according to the manufacturer's instructions. cDNA (62.5 ng) was amplified using TaqMan probes for mouse IGF-I receptor (IGF-IR), and rRNA 18S as endogenous control (ThermoFisher Scientific). Each sample was run in triplicate in $20 \mu \mathrm{l}$ of reaction volume using TaqMan Universal PCR Master Mix according to the manufacturer's instructions (ThermoFisher Scientific). All reactions were performed in a 7500 Real Time PCR system (ThermoFisher Scientific). Quantitative real time PCR analysis was carried out as described (69). Results were expressed as relative expression ratios on the basis of group means for target transcripts versus reference $18 \mathrm{~S}$ transcript.

For behavioral tests, both sexes were used and balanced between experimental groups. Since wild type and control littermates performed similarly in the tests, they were pooled and presented as a single control group. We performed the following three behavioral tests:

(1) Gap-crossing test. To assess sensory perception through the whiskers we used the gap-crossing test that consists of a series of trials in which the mouse has to cross a gap with increasing distances (70)(71). Each mouse was placed in the center of an elevated platform $(5 \mathrm{~cm}$ wide, $9 \mathrm{~cm}$ long) connected to a safe black cylindrical tube $(8 \mathrm{~cm}$ diameter, $9 \mathrm{~cm}$ long). Gap distance between the platform and the cylindrical tube ranged from 0 to $8 \mathrm{~cm}$ in $1 \mathrm{~cm}$ increments. The test was performed under infrared lighting, the trials were recorded with a video camera and the maximum distance crossed by each animal was measured. 
(2) Y-maze spontaneous alternation test. Working memory was assessed by recording spontaneous activity while exploring a Y-maze (72). The maze was made of blackpainted wood and each arm was $25 \mathrm{~cm}$ long, $14 \mathrm{~cm}$ high, $5 \mathrm{~cm}$ wide, and positioned at equal angles. Trials lasted 8 min each. After each trial, the maze was cleaned with $70 \%$ ethanol to remove olfactory cues. Offline analysis of the videos was carried out to obtain the sequence of entries during the test. Alternate behavior was calculated as the percentage of real alternations (number of triplets with non-repeated entries) versus total alternation opportunities (total number of triplets).

(3) Whisker discrimination test. To assess the ability of the animals to discriminate different textures with their whiskers, we adapted the two-trial Y-maze test described in previous work (73)(74). The apparatus was constructed in black-painted wood with three arms, each $25 \mathrm{~cm}$ long, $5 \mathrm{~cm}$ wide, and $14 \mathrm{~cm}$ high. The walls of the maze arms were covered with two different grades of black sandpaper. While two arms (familiar) were covered with a 500 grit sandpaper, the third (novel) was covered with one of 220 grit. Since the three arms of the maze are identical, and there are no extra-maze cues, discrimination of novelty vs familiarity relies only on the different textures that the animal can perceive with the whiskers. Experiments were conducted in a room with dim illumination (6 lux). During the acquisition phase, mice were placed at the end of one of the familiar arms (in a random order) and were allowed to explore both familiar arms (500 grit sandpaper) for $5 \mathrm{~min}$ while the third arm (novel; 220 grit sandpaper) was closed with a guillotine door. At the end of the first trial, mice were returned to their home cage for $5 \mathrm{~min}$. In the retrieval phase, the mice were placed again at the end of the same arm where they started the acquisition phase, and allowed to freely explore all three arms for $5 \mathrm{~min}$. To remove possible olfactory cues, the maze was cleaned with $70 \%$ ethanol between the trials. The time spent in each of the arms was recorded using a 
video camera, and the discrimination index [novel arm/ (novel+familiar arms)] $\times 100$ calculated.

Data analysis: Electrophysiological data analysis was done in Clampfit 10 (Axon Instrument) and Image (NIH, Bethesda, Maryland, USA) was used for the calcium imaging. Graphs were drawn in SigmaPlot 11 (Systat Software Inc, San Jose, CA, USA). Fluorescence values are given as $\Delta F / F_{0}\left(\Delta F / F_{0}=100 \times\left(F-F_{0}\right) / F_{0}\right)$, where $F_{0}$ is the pre-stimulus fluorescence level when cells were at rest, and F is the fluorescence at different times during activity. We used the Student's two-tailed $t$-tests for unpaired or paired data as required in the electrophysiology experiments. Data are presented as means \pm SEM. The threshold for statistical significance was $P<0.05(*) ; P<0.01(* *)$ and $P<0.001(* * *)$ for the Student's test. Statistical analysis was performed using GraphPad Prism 5.0 (La Jolla, CA, USA). To compare differences between two groups and compare multiple variables, two-way ANOVA was used, followed by a Bonferroni post hoc test to compare replicate means. Statistical differences were considered when $p$ $<0.05$. Results are presented as mean \pm SEM of five independent experiments. $\left({ }^{*} \mathrm{p}<\right.$ $0.05, * * \mathrm{p}<0.01, * * * \mathrm{p}<0.001)$

\section{REFERENCES}

1. E. Carro, A. Nuñez, S. Busiguina, I. Torres-Aleman, Circulating insulin-like growth factor I mediates effects of exercise on the brain. Trends in Neurosciences 29, 474-480 (2000).

2. T. Nishijima, et al., Neuronal Activity Drives Localized Blood-Brain-Barrier Transport of Serum Insulin-like Growth Factor-I into the CNS. Neuron 67, 834846 (2010).

3. A. Quesada, H. E. Romeo, P. Micevych, Distribution and localization patterns of estrogen receptor- $\beta$ and insulin-like growth factor-1 receptors in neurons and glial cells of the female rat substantia nigra: Localization of ER $\beta$ and IGF-1R in substantia nigra. Journal of Comparative Neurology 503, 198-208 (2007).

4. H. S. Suh, M. L. Zhao, L. Derico, N. Choi, S. C. Lee, Insulin-like growth factor 1 
and 2 (IGF1, IGF2) expression in human microglia: Differential regulation by inflammatory mediators. Journal of Neuroinflammation 10, 805 (2013).

5. A. I. Rodriguez-Perez, A. Borrajo, C. Diaz-Ruiz, P. Garrido-Gil, J. L. Labandeira-Garcia, Crosstalk between insulin-like growth factor-1 and angiotensin-II in dopaminergic neurons and glial cells: role in neuroinflammation and aging. Oncotarget 7 (2016).

6. A. Nuñez, E. Carro, I. Torres-Alemán, Insulin-like growth factor I modifies electrophysiological properties of rat brain stem neurons. Journal of neurophysiology 89, 3008-3017 (2003).

7. N. Gazit, et al., IGF-1 Receptor Differentially Regulates Spontaneous and Evoked Transmission via Mitochondria at Hippocampal Synapses. Neuron 89, 583-597 (2016).

8. L. Nilsson, V. R. Sara, A. Nordberg, Insulin-like growth factor 1 stimulates the release of acetylcholine from rat cortical slices. Neuroscience Letters 88, 221226 (1988).

9. D. M. Araujo, P. A. Lapchak, B. Collier, J. G. Chabot, R. Quirion, Insulin-like growth factor-1 (somatomedin-C) receptors in the rat brain: distribution and interaction with the hippocampal cholinergic system. Brain Research 484, 130138 (1989).

10. M. A. Castro-Alamancos, I. Torres-Aleman, Long-term depression of glutamateinduced gamma-aminobutyric acid release in cerebellum by insulin-like growth factor I. Proceedings of the National Academy of Sciences of the United States of America 82, 11-20 (1993).

11. D. Seto, et al., Insulin-like growth factor-I inhibits endogenous acetylcholine release from the rat hippocampal formation: Possible involvement of GABA in mediating the effects. Neuroscience 115, 603-612 (2002).

12. J. F. Maya-Vetencourt, et al., IGF-1 restores visual cortex plasticity in adult life by reducing local GABA levels. Neural Plasticity 2012, 1-10 (2012).

13. Z. Liu, et al., IGF1-Dependent Synaptic Plasticity of Mitral Cells in Olfactory Memory during Social Learning. Neuron 95, 106-122.e5 (2017).

14. A. Araque, G. Carmignoto, P. G. Haydon, Dynamic Signaling Between Astrocytes and Neurons. Annual Review of Physiology 63, 795-813 (2001).

15. M. Nedergaard, B. Ransom, S. A. Goldman, New roles for astrocytes: Redefining the functional architecture of the brain. Trends in Neurosciences 26, 523-530 (2003).

16. A. Volterra, J. Meldolesi, Astrocytes, from brain glue to communication elements: The revolution continues. Nature Reviews Neuroscience 6, 626-640 (2005).

17. P. G. Haydon, G. Carmignoto, Astrocyte Control of Synaptic Transmission and Neurovascular Coupling. Physiological Reviews 86, 1009-1031 (2006). 
18. G. Perea, M. Navarrete, A. Araque, Tripartite synapses: astrocytes process and control synaptic information. Trends in Neurosciences 32, 421-431 (2009).

19. V. Parpura, R. Zorec, Gliotransmission: Exocytotic release from astrocytes. Brain Research Reviews 63, 83-92 (2010).

20. P. Singh, et al., Single-vesicle architecture of synaptobrevin2 in astrocytes. Nature Communications 5, 3780 (2014).

21. N. C. Chisholm, F. Sohrabji, Astrocytic response to cerebral ischemia is influenced by sex differences and impaired by aging. Neurobiology of Disease 85, 245-253 (2016).

22. I. OCRANT, et al., Structural and Immunohistochemical Characterization of Insulin-Like Growth Factor I and II Receptors in the Murine Central Nervous System*. Endocrinology 123, 1023-1034 (1988).

23. X. Zhou, J. P. Herman, C. M. Paden, Evidence That IGF-I Acts as an Autocrine/Paracrine Growth Factor in the Magnocellular Neurosecretory System: Neuronal Synthesis and Induction of Axonal Sprouting. Experimental Neurology 159, 419-432 (1999).

24. C. J. Garwood, et al., Insulin and IGF1 signalling pathways in human astrocytes in vitro and in vivo; characterisation, subcellular localisation and modulation of the receptors. Molecular Brain 8, 51 (2015).

25. E. Hernandez-Garzón, et al., The insulin-like growth factor I receptor regulates glucose transport by astrocytes. GLIA 64, 1962-1971 (2016).

26. I. Torres-Aleman, M. Villalba, M. . Nieto-Bona, Insulin-like growth factor-I modulation of cerebellar cell populations is developmentally stage-dependent and mediated by specific intracellular pathways. Neuroscience 83, 321-334 (1998).

27. D. Chesik, N. Wilczak, J. De Keyser, IGF-1 regulates cAMP levels in astrocytes through a $\beta 2$-adrenergic receptor-dependant mechanism. International Journal of Medical Sciences, 240-243 (2008).

28. J. Kang, L. Jiang, S. A. Goldman, M. Nedergaard, Astrocyte-mediated potentiation of inhibitory synaptic transmission. Nature Neuroscience 1, 683-692 (1998).

29. G. Perea, et al., Activity-dependent switch of gabaergic inhibition into glutamatergic excitation in astrocyte-neuron networks. eLife 5, e20362 (2016).

30. A. Serrano, GABAergic Network Activation of Glial Cells Underlies Hippocampal Heterosynaptic Depression. Journal of Neuroscience 26, 53705382 (2006).

31. M. Andersson, F. Blomstrand, E. Hanse, Astrocytes play a critical role in transient heterosynaptic depression in the rat hippocampal CA1 region. Journal of Physiology 585, 843-852 (2007).

32. J. Chen, et al., Heterosynaptic long-term depression mediated by ATP released from astrocytes. GLIA 61, 178-191 (2013). 
33. U. Lalo, et al., Exocytosis of ATP From Astrocytes Modulates Phasic and Tonic Inhibition in the Neocortex. PLoS Biology 12, e1001747 (2014).

34. R. S. Zucker, Calcium- and activity-dependent synaptic plasticity. Current Opinion in Neurobiology 9, 305-313 (1999).

35. A. Araque, et al., Gliotransmitters travel in time and space. Neuron 81, 728-739 (2014).

36. M. Navarrete, A. Araque, Endocannabinoids potentiate synaptic transmission through stimulation of astrocytes. Neuron 68, 113-126 (2010).

37. M. A. Di Castro, et al., Local Ca2+detection and modulation of synaptic release by astrocytes. Nature Neuroscience 14, 1276-1284 (2011).

38. A. Panatier, et al., Astrocytes are endogenous regulators of basal transmission at central synapses. Cell 146, 785-798 (2011).

39. M. Navarrete, A. Araque, Endocannabinoids potentiate synaptic transmission through stimulation of astrocytes. Neuron 68, 113-126 (2010).

40. R. Martín, R. Bajo-Grañeras, R. Moratalla, G. Perea, A. Araque, Circuit-specific signaling in astrocyte-neuron networks in basal ganglia pathways. Science 349, 730-734 (2015).

41. R. Min, T. Nevian, Astrocyte signaling controls spike timing-dependent depression at neocortical synapses. Nature Neuroscience 15, 746-753 (2012).

42. C. Agulhon, T. A. Fiacco, K. D. McCarthy, Hippocampal Short- and Long-Term Plasticity Are Not Modulated by Astrocyte Ca2+ Signaling. Science 327, 12501254 (2010).

43. R. Srinivasan, et al., $\mathrm{Ca}^{2+}$ signaling in astrocytes from $\mathrm{Ip} 3 \mathrm{r} 2^{-/-}$mice in brain slices and during startle responses in vivo. Nature Neuroscience 18, 708-717 (2015).

44. A. Pinto $\square$ Duarte, A. J. Roberts, K. Ouyang, T. J. Sejnowski, Impairments in remote memory caused by the lack of Type 2 IP 3 receptors. Glia, glia.23679 (2019).

45. M. A. Castro-Alamancos, M. A. Arevalo, I. Torres-Aleman, Involvement of protein kinase $\mathrm{C}$ and nitric oxide in the modulation by insulin-like growth factorI of glutamate-induced GABA release in the cerebellum. Neuroscience 70, 843847 (1996).

46. K. Suzuki, et al., Transient upregulation of the glial glutamate transporter GLAST in response to fibroblast growth factor, insulin-like growth factor and epidermal growth factor in cultured astrocytes. Journal of cell science 114, 371725 (2001).

47. M. Hamai, Y. Minokoshi, T. Shimazu, L-Glutamate and Insulin Enhance Glycogen Synthesis in Cultured Astrocytes from the Rat Brain Through Different Intracellular Mechanisms. Journal of Neurochemistry 73, 400-407 (2002). 
48. L. Genis, et al., Astrocytes require insulin-like growth factor I to protect neurons against oxidative injury. F1000Research 3, 28 (2014).

49. W. Cai, et al., Insulin regulates astrocyte gliotransmission and modulates behavior. Journal of Clinical Investigation 128, 2914-2926 (2018).

50. P. B. Guthrie, et al., ATP Released from Astrocytes Mediates Glial Calcium Waves. The Journal of Neuroscience 19, 520-528 (1999).

51. M. Navarrete, A. Araque, Endocannabinoids Mediate Neuron-Astrocyte Communication. Neuron 57, 883-893 (2008).

52. L. Pasti, A. Volterra, T. Pozzan, G. Carmignoto, Intracellular Calcium Oscillations in Astrocytes: A Highly Plastic, Bidirectional Form of Communication between Neurons and Astrocytes In Situ . The Journal of Neuroscience 17, 7817-7830 (2018).

53. R. Min, M. Santello, T. Nevian, The computational power of astrocyte mediated synaptic plasticity. Frontiers in Computational Neuroscience 6, 93 (2012).

54. M. De Pittà, N. Brunel, A. Volterra, Astrocytes: Orchestrating synaptic plasticity? Neuroscience 11, 427 (2016).

55. S. Guerra-Gomes, N. Sousa, L. Pinto, J. F. Oliveira, Functional Roles of Astrocyte Calcium Elevations: From Synapses to Behavior. Frontiers in Cellular Neuroscience 11, 427 (2018).

56. I. Savtchouk, A. Volterra, Gliotransmission: Beyond Black-and-White. The Journal of Neuroscience 38, 14-25 (2018).

57. O. Pascual, et al., Astrocytic Purinergic Signaling Coordinates Synaptic Networks. Science 310, 113-116 (2005).

58. M. Martin-Fernandez, et al., Synapse-specific astrocyte gating of amygdalarelated behavior. Nature Neuroscience 20, 1540-1548 (2017).

59. J. Csicsvari, B. Jamieson, K. D. Wise, G. Buzsáki, Mechanisms of gamma oscillations in the hippocampus of the behaving rat. Neuron 37, 311-322 (2003).

60. T. K. Hensch, Critical period plasticity in local cortical circuits. Nature Reviews Neuroscience 6, 877-888 (2005).

61. H. S. Lee, et al., Astrocytes contribute to gamma oscillations and recognition memory. Proceedings of the National Academy of Sciences 111, E3343-E3352 (2014).

62. R. Creager, T. Dunwiddie, G. Lynch, Paired $\square$ pulse and frequency facilitation in the CA1 region of the in vitro rat hippocampus. The Journal of Physiology 299, 409-424 (1980).

63. K. A. Clark, A. D. Randall, G. L. Collingridge, A comparison of paired-pulse facilitation of AMPA and NMDA receptor-mediated excitatory postsynaptic currents in the hippocampus. Experimental Brain Research 101, 272-278 (1994).

64. U. Kuhnt, L. L. Voronin, Interaction between paired-pulse facilitation and long- 
term potentiation in area cal of guinea-pig hippocampal slices: Application of quantal analysis. Neuroscience 62, 391-397 (1994).

65. A. M. Fernandez, S. Fernandez, P. Carrero, M. Garcia-Garcia, I. Torres-Aleman, Calcineurin in Reactive Astrocytes Plays a Key Role in the Interplay between Proinflammatory and Anti-Inflammatory Signals. Journal of Neuroscience 27, 8745-8756 (2007).

66. Y. M. Ganat, et al., Early Postnatal Astroglial Cells Produce Multilineage Precursors and Neural Stem Cells In Vivo. Journal of Neuroscience 26, 86098621 (2006).

67. P. G. Hirrlinger, A. Scheller, C. Braun, J. Hirrlinger, F. Kirchhoff, Temporal control of gene recombination in astrocytes by transgenic expression of the tamoxifen-inducible DNA recombinase variant CreERT2. Glia 54, 11-20 (2006).

68. C. García-Cáceres, et al., Astrocytic Insulin Signaling Couples Brain Glucose Uptake with Nutrient Availability. Cell 166, 867-880 (2016).

69. M. W. Pfaffl, A new mathematical model for relative quantification in real-time RT-PCR. Nucleic Acids Research 29, 45e-45 (2001).

70. K. A. Hutson, R. B. Masterton, The sensory contribution of a single vibrissa's cortical barrel. Journal of Neurophysiology 56, 1196-1223 (1986).

71. P. Barnéoud, M. Gyger, F. Andrés, H. van der Loos, Vibrissa-related behavior in mice: transient effect of ablation of the barrel cortex. Behavioural Brain Research 44, 87-99 (1991).

72. M. Sarter, G. Bodewitz, D. N. Stephens, Attenuation of scopolamine-induced impairment of spontaneous alternation behaviour by antagonist but not inverse agonist and agonist $\square$ ?-carbolines. Psychopharmacology 94, 491-495 (1988).

73. F. Dellu, A. Contarino, H. Simon, G. F. Koob, L. H. Gold, Genetic Differences in Response to Novelty and Spatial Memory Using a Two-Trial Recognition Task in Mice. Neurobiology of Learning and Memory 73, 31-48 (2000).

74. T. J. Hausrat, et al., Radixin regulates synaptic GABA A receptor density and is essential for reversal learning and short-term memory. Nature Communications 6, $6872(2015)$.

\section{ACKNOWLEDGMENTS}

This work was supported by the following Grants: BFU2016-80802-P AEI/FEDER, UE (MINECO) to D. Fernández de Sevilla, National Institutes of Health-NINDS (R01NS097312 and R01DA048822) to A. Araque and grants from Ciberned and SAF2016-76462-C2-1-P (MINECO) to I. Torres-Aleman. JAZV acknowledges the support from the National Council of Science, Technology and Technological Innovation (CONCYTEC, Perú) through the National Fund for Scientific and 
Technological Development (FONDECYT, Perú). JF received a post-doc fellowship from Fundação de Amparo à Pesquisa do Estado de São Paulo (FAPESP: \# 2017/14742-0; \# 2019/03368-5). We thank the University of Minnesota Viral Vector and Cloning Core for production of some of the viral vectors used in this study. The authors thank Dr. J. Chen (UCSD, CA, USA) for providing $\mathrm{IP}_{3} \mathrm{R} 2^{-/}$mice and Dra G. Perea for helpful comments.

\section{AUTHOR CONTRIBUTIONS}

Noriega-Prieto and Fernandez de Sevilla conceived the study. Noriega Prieto, Maglio performed and analyzed electrophysiological, and calcium imaging experiments, analyzed the data and wrote the methods. Jonathan and Jansen designed and performed behavioral tests and wrote the methods. MartinezRachadell performed behavioral tests. Fernandez performed the in vitro tests with astrocytes, characterized $\mathrm{IGF}_{\mathrm{IR}}{ }^{-/-}$mice and wrote the methods and results. Pignatelli prepared and validated the virus and the $\mathrm{IGF}_{\mathrm{IR}}{ }^{-/-}$mice. Torres-Aleman, Araque, Nuñez and Fernandez de Sevilla designed, coordinated, interpreted experiments and wrote part of the manuscript. All the authors read and edited the manuscript.

\section{FIGURE LEGENDS}

Figure 1. IGF-I mediated Astrocyte signaling induces LTD of IPSCs. A. left. Representative drawing of location of brain section (top) and slice treated with cytochrome oxidase (bottom) of barrel cortex. Right. DIC image of slice showing the stimulation (stim) and recording (rec) electrodes (scale bar, $100 \mu \mathrm{m})$. B. Left. Time course of IPSCs peak amplitude in ACSF (black circles) and in presence of NVP (white circles) showing the effect of IGF-I bath application. Right. Representative IPSCs in ACSF and NVP before and during IGF-I. C. Left. Same as B left in ACSF but with 
intracellular BAPTA. Right. Same as B right in ACSF but with intracellular BAPTA. D. Left. PPR of the IPSCs in ACSF, NVP and intracellular BAPTA. Right. Representative IPSCs evoked by paired pulse stimulation in ACSF before and during IGF-I. E. Top. Pseudocolor $\mathrm{Ca}^{2+}$ images showing the intensities of GCaMP6f expressing astrocytes in barrel cortex, before and during IGF-I application in slices from IGF-IR ${ }^{\mathrm{WT}}$ mice (scale bar, $50 \mu \mathrm{m})$. Bottom. Representative calcium traces in astrocytes from IGF-IR ${ }^{\mathrm{WT}}$ mice. $\boldsymbol{F}$. Bar plot of the calcium oscillation frequency in astrocytes from IGF-IR ${ }^{\mathrm{WT}}$ mice before and during IGF-I. G. Same as H but in the presence of NVP. $\boldsymbol{H}$. Same as B left in ACSF but after 30 min of BAPTA loaded astrocyte. I. Same as D left in ACSF but after 30 min of BAPTA loaded astrocyte.

\section{Figure 2. Removal of IGF-IR in astrocytes avoid the iLTD}

A. Schema of experimental procedure showing the local injection of GFAP-mCherryCRE (or AAV8-GFAP-mCherry as a control) and GFAP-GCaMP6f. B. Representatives images of locally targeting astrocytes with GFAP-GCaMP6f and GFAP-mCherry for IGF-IR $^{\text {WT }}$ (upper images, green and red images), and GFAP-GCaMP6f and GFAPmCheryy-CRE for IGF-IR ${ }^{-/-}$(lower images, green and red images). C. Same as 1B left in ACSF but in IGF-IR ${ }^{-/-}$and IGF-IR ${ }^{\mathrm{WT}}$ mice (green and yellow circles respectively). $\boldsymbol{D}$. Left. PPR of the IPSCs in IGF-IR ${ }^{-/-}$and IGF-IR ${ }^{\text {WT }}$ mice before and during IGF-I application. Right. Representative IPSCs evoked by paired pulse stimulation in IGF-IR ${ }^{-}$ /- and IGF-IR ${ }^{\mathrm{WT}}$ mice before and during IGF-I. E. Left. Same as $1 \mathrm{G}$ Top but in IGF-IR ${ }^{-/}$ mice (scale bar, $50 \mu \mathrm{m}$ ). Right. Representative calcium traces in astrocytes from IGF$\mathrm{IR}^{-/-}$mice. $\boldsymbol{F}$. Same as $1 \mathrm{H}$ but from $\mathrm{IGF}-\mathrm{IR}^{-/-}$mice.

\section{Figure 3. $i L T D_{I G F I}$ requires $A_{2 A}$ receptor activation}


A. Left. Same as 1B left in ACSF but in the presence of SCH or CPT (purple and blue circles respectively). Note that the $\mathrm{A}_{2 \mathrm{~A}}$ receptor antagonist, $\mathrm{SCH}$, prevents the iLTD $\mathrm{IGFI}_{\text {. }}$ Right. Representative IPSCs in SCH and CPT before and during IGF-I. B. Same as 1D left but in the presence of SCH and CPT. C. Left. Bar plot of the calcium oscillation frequency in astrocytes in ACSF, SCH or CPT, before and during IGF-I. Right. Representative calcium traces in astrocytes under SCH or CPT, before and during IGFI. D. Bar plot of ATP concentration in culture of astrocytes before (control) and during IGF-I exposure, and in IGF-I + NVP, IGF-I + BAPTA-AM and IGF-I + thapsigargin. $\boldsymbol{E}$. Bar plot of ATP concentration culture of astrocytes before (control) and during IGF-I exposure from IGF-IR ${ }^{\mathrm{WT}}$ (yellow bar), IGF-IR ${ }^{-/-}$mice (green bar) and $\mathrm{IP}_{3} \mathrm{R}^{-/-}$mice (gold bar).

\section{Figure 4. iLTD $_{I G F I}$ is absent in IP $P_{3} R 2-n u l l$ mice}

A. Left. Same as 1B left in ACSF but in the presence of MPEP + LY367385. Note that in the presence of the group I mGluR-antagonists, the iLTD IGFI is already evoked. Right. Representative IPSCs in MPEP + LY367385 before and during IGF-I. B. Same as 1D left but in the presence of MPEP + LY367385. C. Left. Same as A left but in $\mathrm{IP}_{3} \mathrm{R} 2^{-/-}$ mice. Right. Same as A right but in $\mathrm{IP}_{3} \mathrm{R} 2^{-/-}$mice. D. Same as $1 \mathrm{D}$ left but in $\mathrm{IP}_{3} \mathrm{R} 2^{-/-}$ mice. $\boldsymbol{E}$. Pseudocolor images from Fluo-4AM showing the somatic calcium elevations on astrocytes before and during IGF-I in control, MPEP $+\mathrm{LY} 367385$ and $\mathrm{IP}_{3} \mathrm{R}^{-/-}$mice (scale bar, $50 \mu \mathrm{m}$ ). $\boldsymbol{F}$. Bar plot of the somatic calcium oscillation frequency in astrocytes in control, MPEP + LY367385 and $\mathrm{IP}_{3} \mathrm{R} 2^{-/-}$mice. G. A schematic representation of the proposed mechanism of the IGF-I-induced astrocyte-mediated LTD of the IPSCs. (1) IGF-IR activation in the astrocytes increases the astrocytic calcium frequency (2) leading to the ATP/Ado release (3) that activates presynaptic 
$\mathrm{A}_{2 \mathrm{~A}} \mathrm{R}$ in the GABAergic terminal (4), decreasing the probability of GABA release (5) that underlies the LTD of the inhibitory synaptic transmission (6).

Figure 5. Impaired whisker-based discrimination in IGF-IR KO mice.

A. Schema of Y maze whisker dependent texture discrimination test. While two arms (familiar) were covered with a 500 grit sandpaper, the third (novel) was covered with one of 220 grit. Since the three arms of the maze are identical, and there are no extramaze cues, discrimination of novelty vs familiarity relies only on the different textures that the animal can perceive with the whiskers. B. IGF-IR ${ }^{-/-}$and control mice show no differences in entrance to the different arms $(\mathrm{p}=0.1142)$. $\boldsymbol{C}$ left. However, control mice spent more time exploring the novel arm (220 grift sandpaper) than IGF-IR ${ }^{-/-}$mice $\left(\mathrm{n}=13,{ }^{*} \mathrm{p}=0,0336\right) . \boldsymbol{C}$ Right. Percentage of time spent in the novel-texture arm was higher in controls than in $\mathrm{IGF}_{\mathrm{IR}}{ }^{-/-}$mice $(* * \mathrm{p}=0,0059$; unpaired student t-test with Welch's correction; control =11, IGF-IR ${ }^{-/-}=13$ ).

\section{SUPPLEMENTARY INFORMATION}

Supplementary Figure 1. Elevations in astrocytes somatic calcium are absent in IP $_{3} R 2$ null mice.

A. Pseudocolor images showing the astrocyte calcium increase during ATP $(100 \mu \mathrm{M})$ bath perfusion in wild type (upper images) and $\mathrm{IP}_{3} \mathrm{R} 2^{-/-}$(bottom images) mice (scale bar, $50 \mu \mathrm{m})$.

Supplementary Figure 2. Postsynaptic BAPTA blocks the intracellular calcium elevations. 
A. Pseudocolor images of recorded cells before and during neuronal depolarization (ND) in control (ACSF, upper images) and with intracellular BAPTA (BAPTA, bottom images; scale bar, $50 \mu \mathrm{m}$ ).

Supplementary Figure 3. Group I mGluR antagonists decrease calcium elevations in astrocytes.

A. Pseudocolor images of Fluo 4AM-filled astrocytes in the presence of TTX $(1 \mu \mathrm{M})$, CNQX $(20 \mu \mathrm{M})$ and D-AP5 $(50 \mu \mathrm{M})$, before and during two consecutive glutamate (10 $\mathrm{mM}$ ) pressure pulses (2 s-duration,) in control (upper images) and during MPEP + LY367385 (bottom images) bath perfusion (scale bar, $50 \mu \mathrm{m}$ ).

Supplementary Figure 4. Preserved sensory perception and working memory in IGFIR KO mice.

A left. Schema of the transgenic mice generation with tamoxifen-regulated deletion of IGF-IR in astrocytes (IGF-IR ${ }^{-/-}$mice). A right, Brain levels of IGF-IR mRNA, as determined by $\mathrm{qPCR}$, are reduced in $\mathrm{IGF}_{\mathrm{IR}}{ }^{-/-}$mice after tamoxifen injection, as compared to vehicle-injected control mice $(* * \mathrm{p}<0.01 ; \mathrm{n}=5$ per group). $\boldsymbol{B}$ left, Schema of the GAP crossing test used to evaluate the sensory perception through the whiskers. The gap-crossing test consists of a series of trials in which the mouse has to cross a gap with increasing distances $(0$ to $8 \mathrm{~cm})$. $\boldsymbol{B}$ right, Control and $\mathrm{IGF}_{\mathrm{IR}}{ }^{-1-}$ mice showed similar performance (control=5, IGF- $\mathrm{IR}^{-/-}=7, \mathrm{p}=0,6199$ ) in the Gap-crossing test, indicating no alterations in the sensory perception.

C left, Schema of Y maze spontaneous alternation test used to examine the Working memory. Spontaneous Alternation was calculated as the percentage of real alternations versus total alternation opportunities. $\boldsymbol{C}$ right, No differences were observed between control and IGF-IR ${ }^{-/-}$mice in the Y-Maze Spontaneous Alternation Task, indicating a 
bioRxiv preprint doi: https://doi.org/10.1101/2020.02.11.942532; this version posted February 12, 2020. The copyright holder for this preprint (which was not certified by peer review) is the author/funder, who has granted bioRxiv a license to display the preprint in perpetuity. It is made available under aCC-BY-NC-ND 4.0 International license.

similar working memory (control=11, IGF-IR ${ }^{-/-}=11, \mathrm{p}=0,7474$; Mann Whitney $\mathrm{U}$

Test). 
A bioRxiv preprint doi: https://doi.org/10.1101/2020.02 11.942532; this version posted February 12, 2020. The copyright holder for this preprint (which was not certified by peer review) is the authoBunder, who has granted pioRxiv a license to displax the preprint in perpetuity. It is made

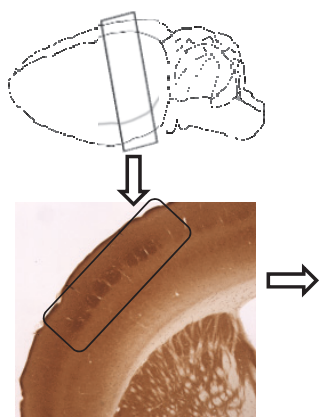

C

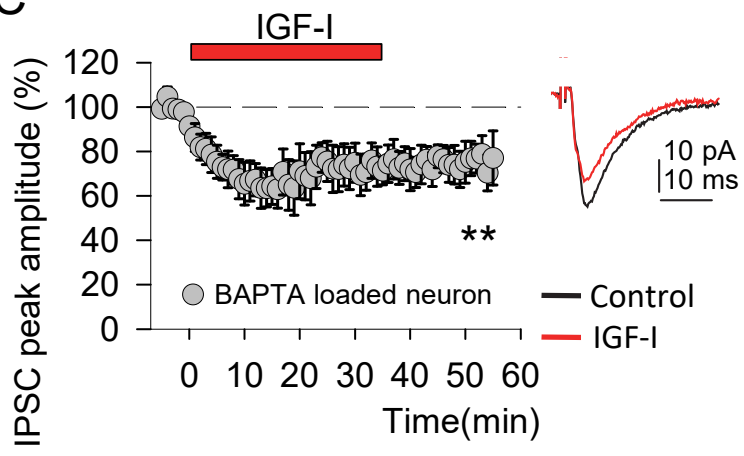

E

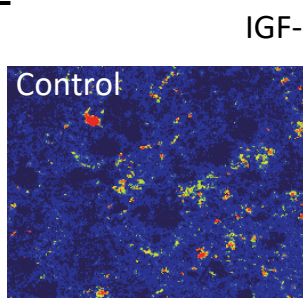

GF-IR ${ }^{W T}$

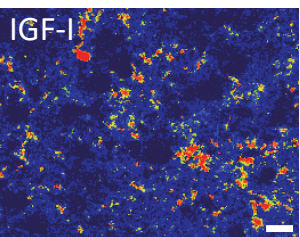

F

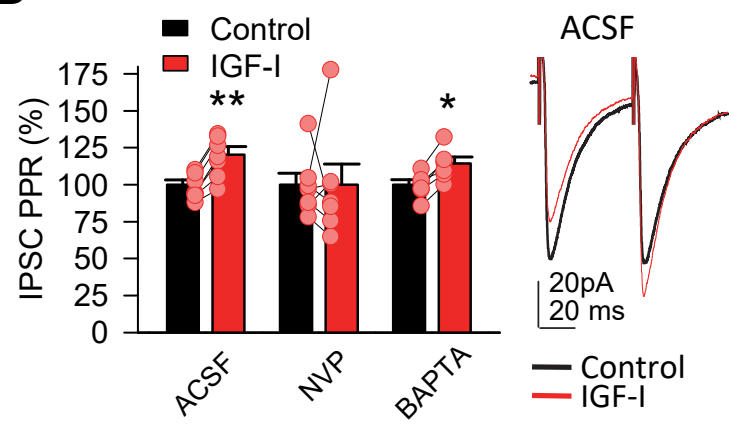

$\mathrm{H}$

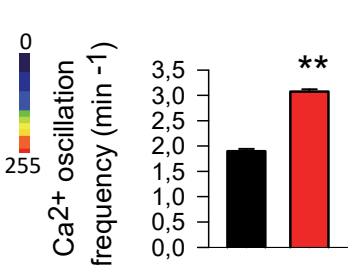

G $\quad$ - Control

$40 \mathrm{~s}$
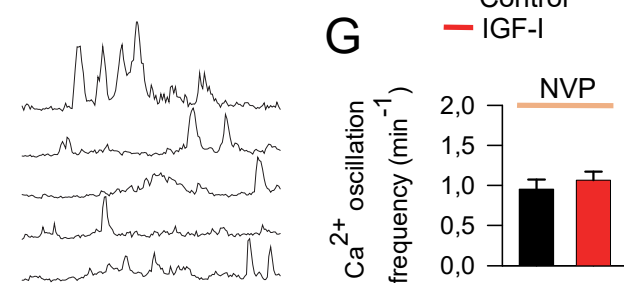

$25 \mathrm{pA}$

NVP

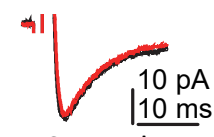

二 Contro 
bioRxiv preprint doi: https://doi.org/10.1101/2020.02.11.942532; this version posted February 12, 2020. The copyright holder for this preprint A (which was not certified by peer review) is the author/funder, who has granted bioRxiv a license to display the preprint in perpetuity. It is made
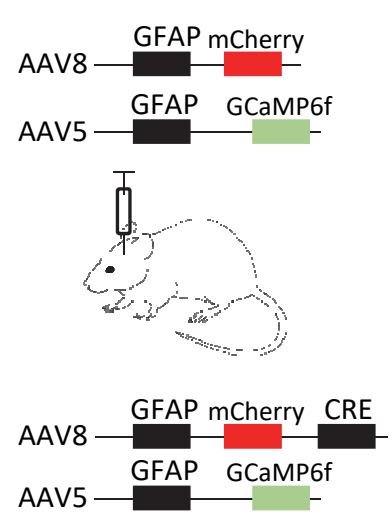

$B^{\text {e }}$ available under aCC-BY-N
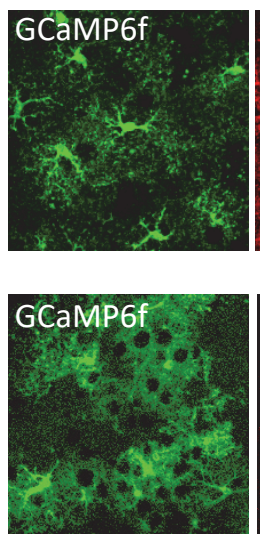

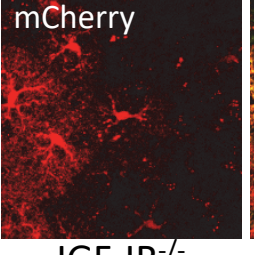

IGF-IR ${ }^{-1-}$

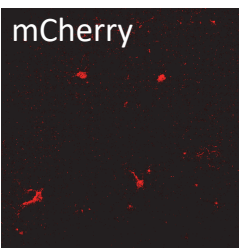

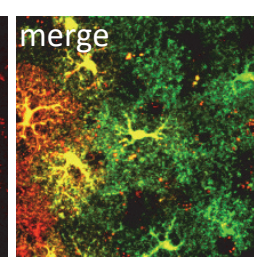

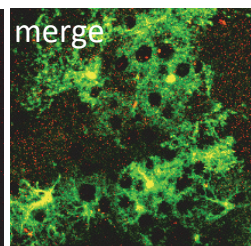

C
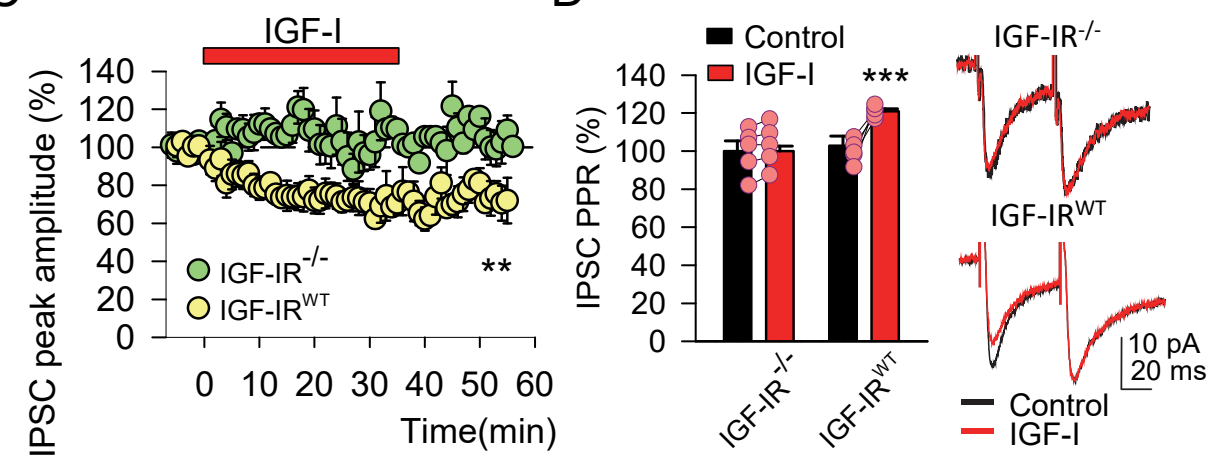

$E$
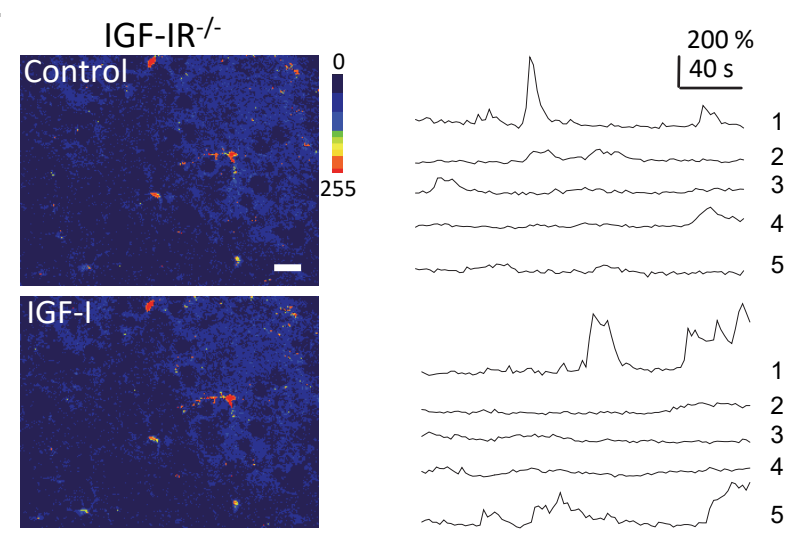

$\mathrm{F}$

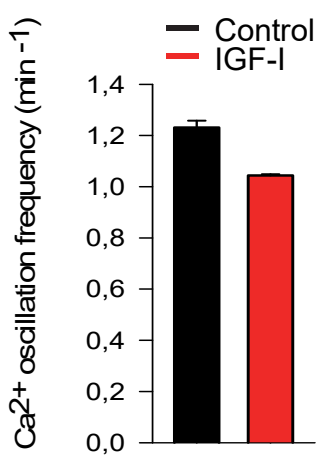


A

B

bioRxiv preprint dpi.attps://doi.org/10.1101/203ep2.11.942532; this version posted February 12, 2020. The copyright holder for this preprint (which was not centfled by peer review) is the author/funder, who has granta b6e日xtvad license to display the preprint in perpetuity. It is made
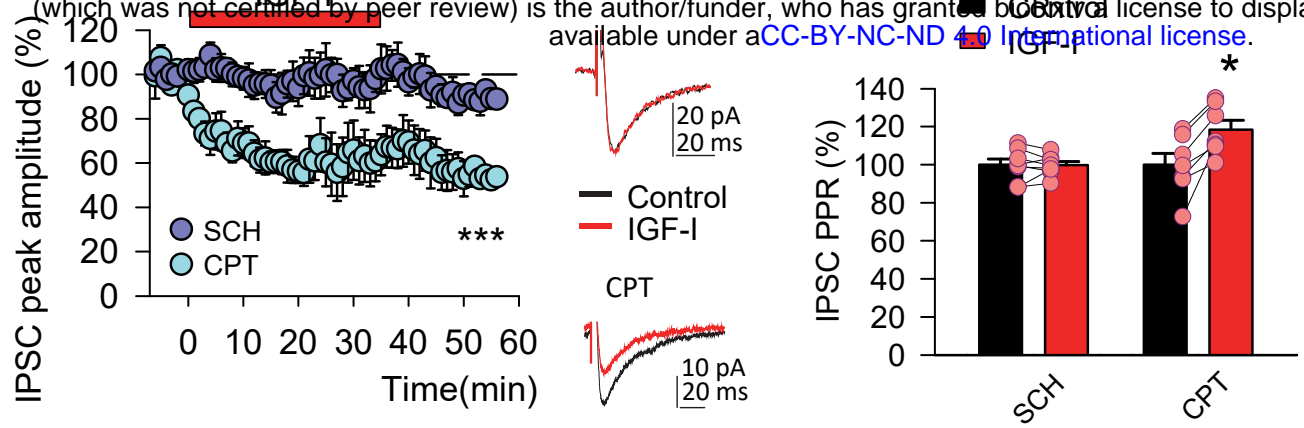

C

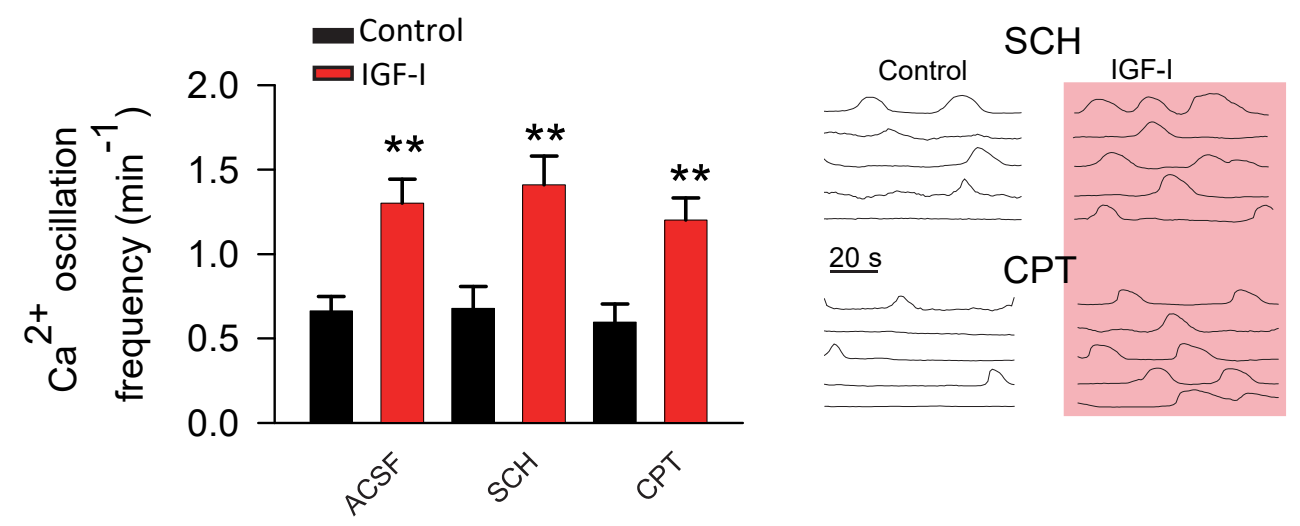

D

$E$
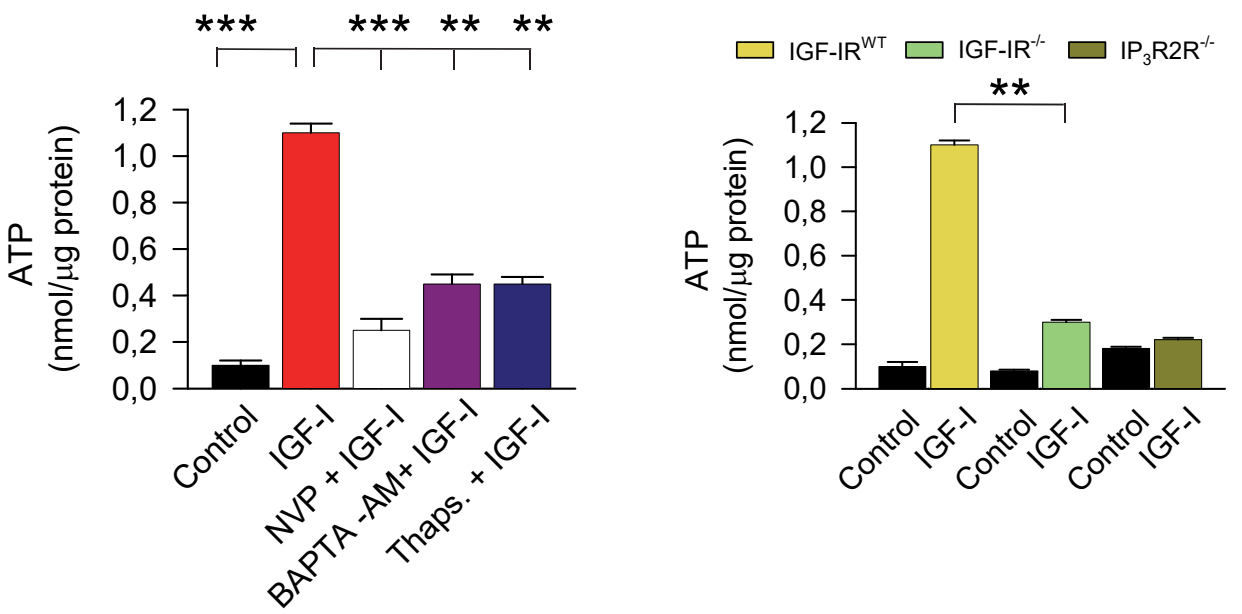
A

B

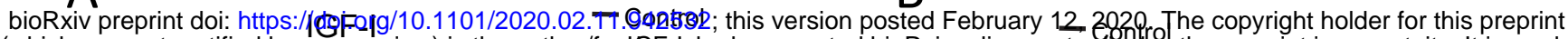
(which was 920 fertified by peer review) is the author/funbef,-lwho has granted bioRxiv a license to gisplay the preprint in perpetuity. It is made
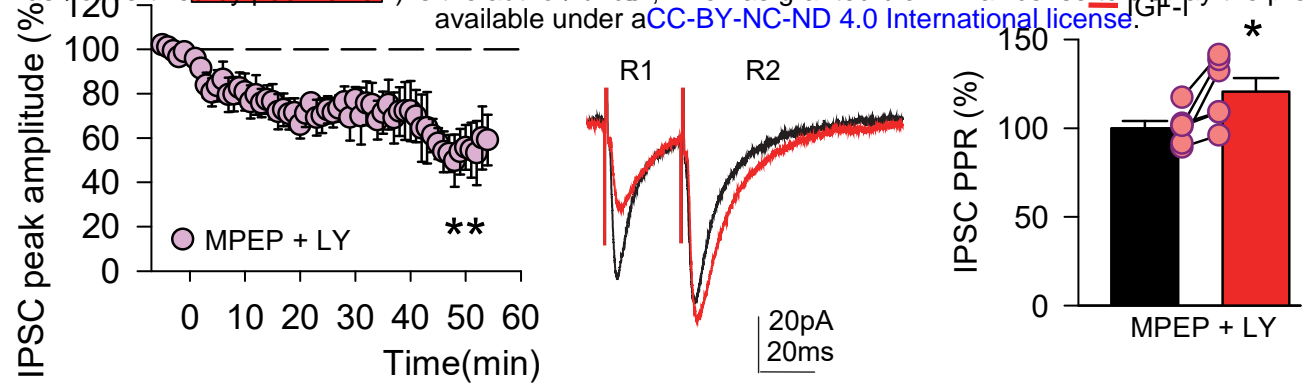

$\mathrm{C}$
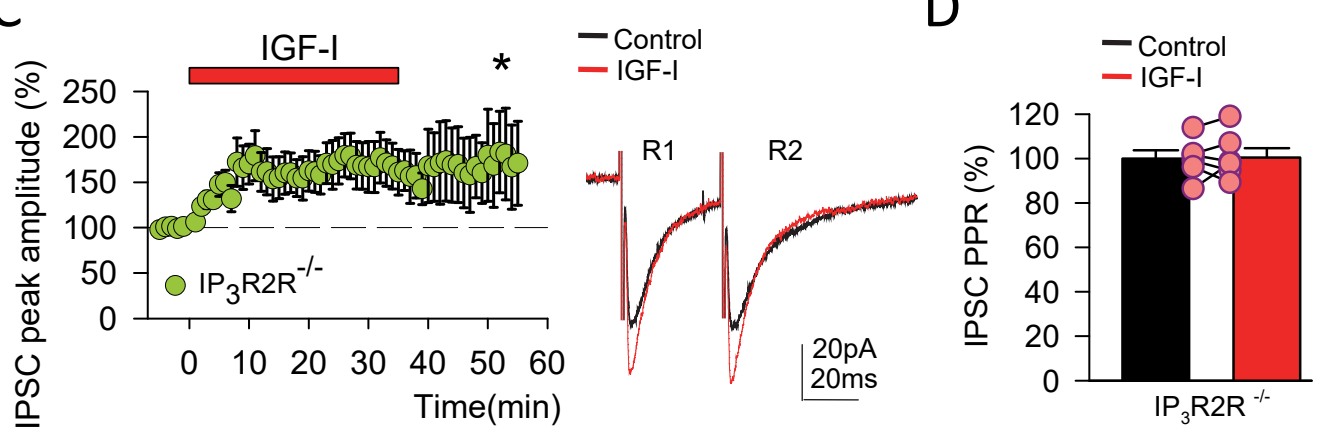

$\mathrm{E}$
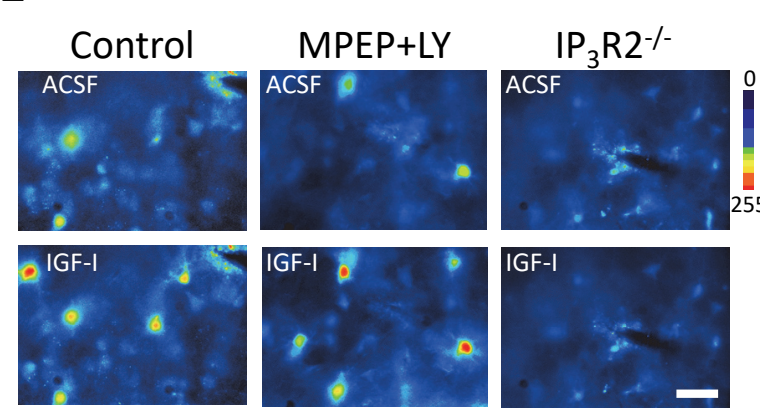

$\mathrm{F}$

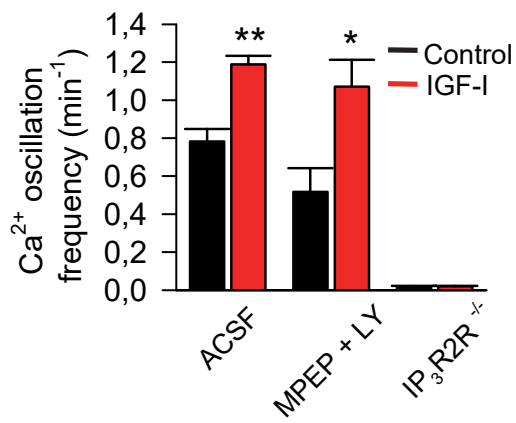

G

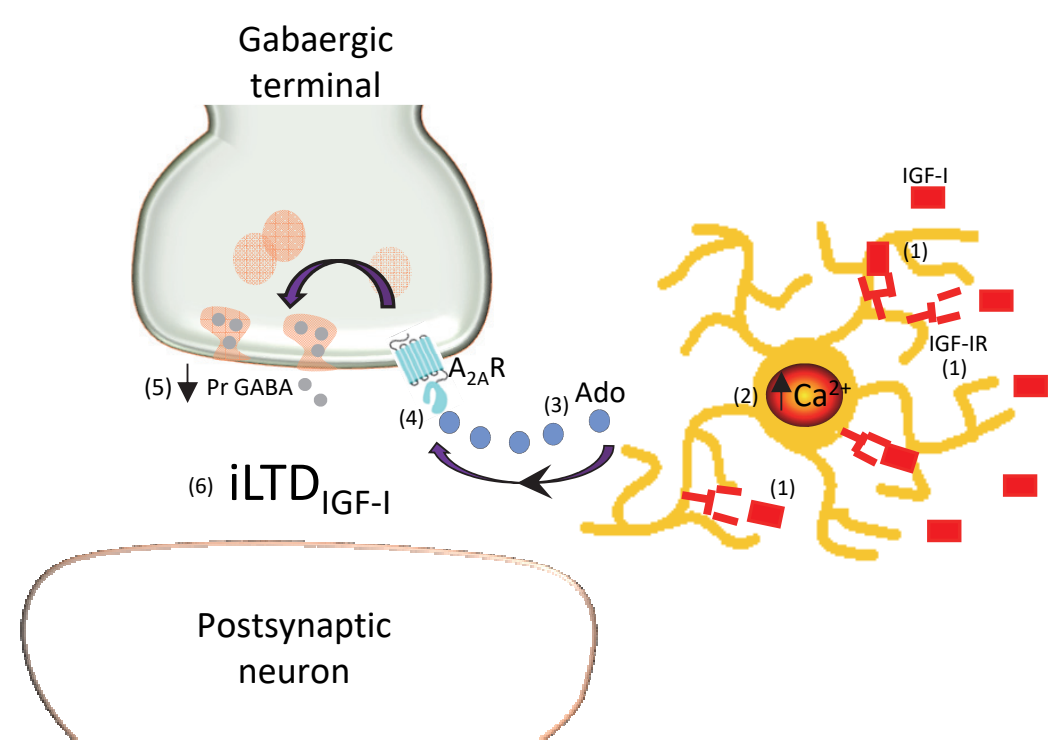


bioRxiv preprint doi: https://doi.org/10.1101/2020.02.11.942532; this version posted February 12, 2020. The copyright holder for this preprint (which was not certified by peer review) is the author/funder, who has granted bioRxiv a license to display the preprint in perpetuity. It is made available under aCC-BY-NC-ND 4.0 International license.

A Y maze texture discrimination test

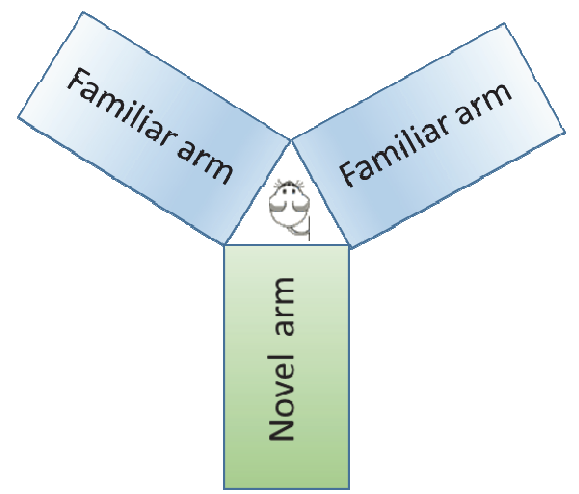

B

Deambulatory activity

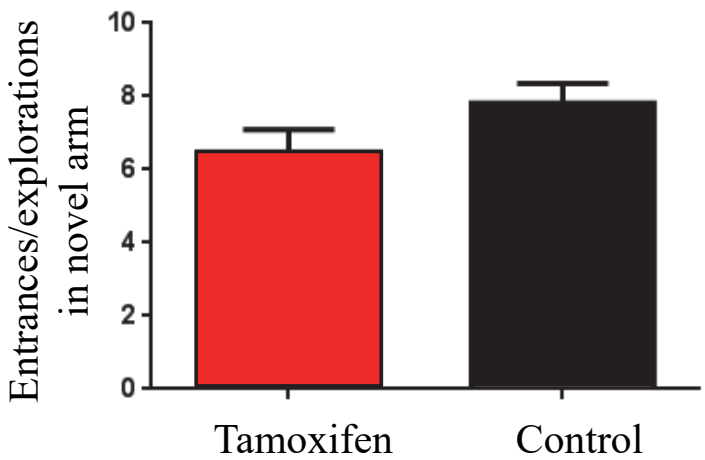

C

Whisker dependent texture discrimination

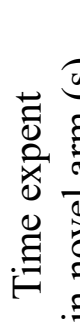

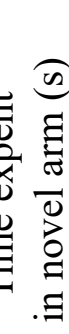

150
100
50

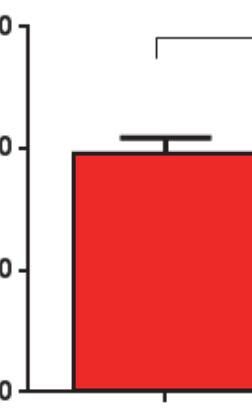

Tamoxifen

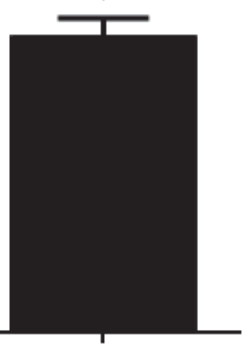

Control

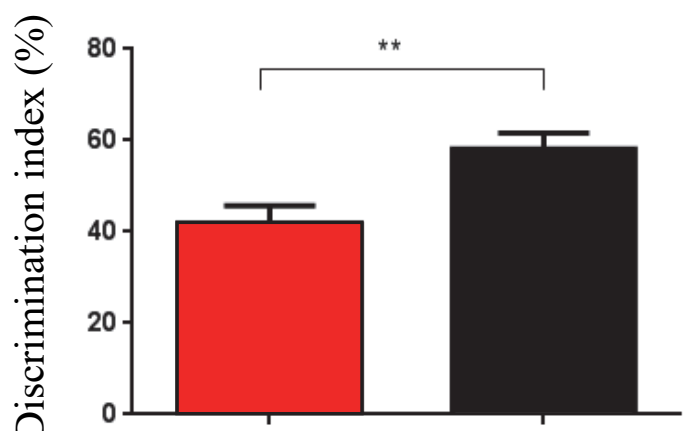

Tamoxifen

Control 
Biof (which was not certAfies Fy peer review) is the author/funder, who has granted bioRxiv a license to display the preprint in perpetuity. It is made

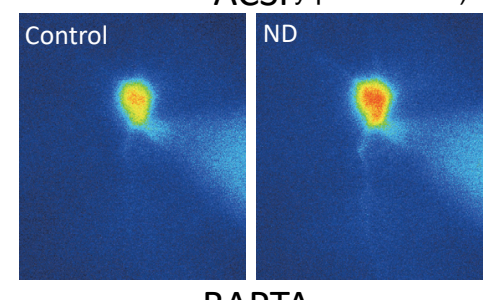

BAPTA

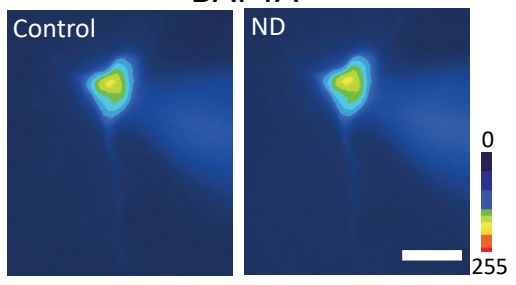


A
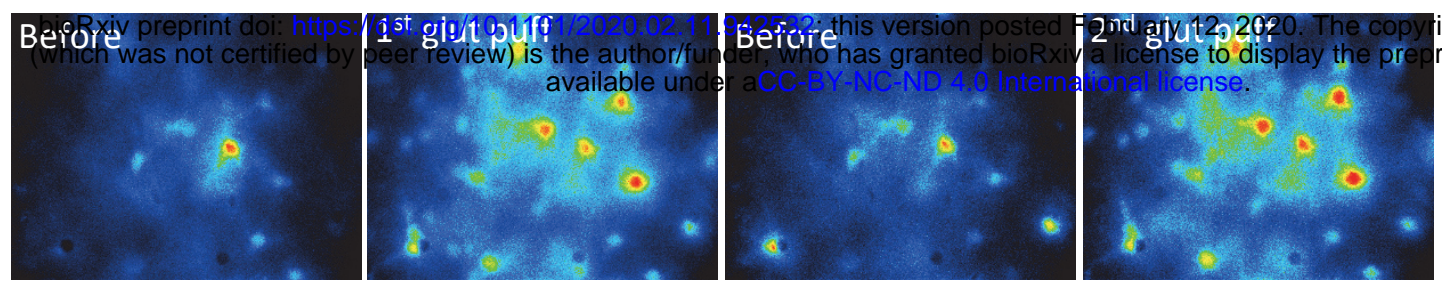

ght holder for this preprint rint in perpetuity. It is made
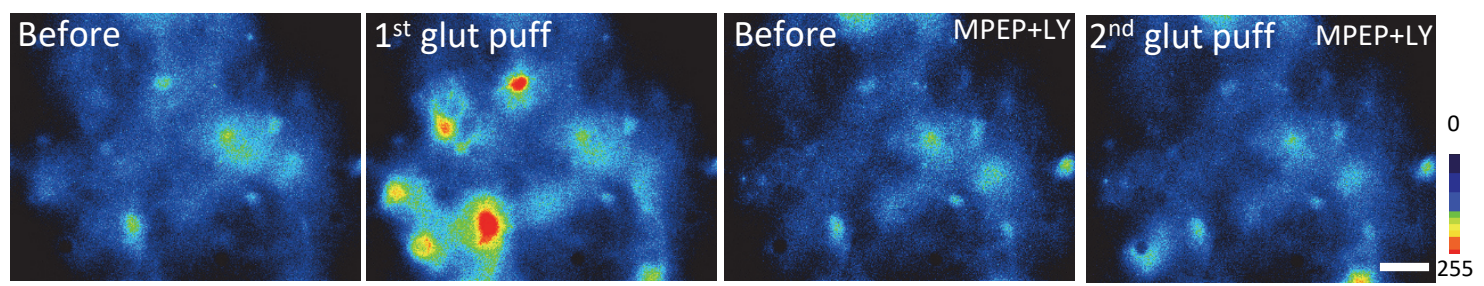
AjoRxiv preprint doi: https://doi.org/10.1101/2020.02.11.942532; this version posted February 12, 2020. The copyright holder for this preprint (which was not certified by peer review) is the author/funder, who has granted bioRxiv a license to display the preprint in perpetuity. It is made
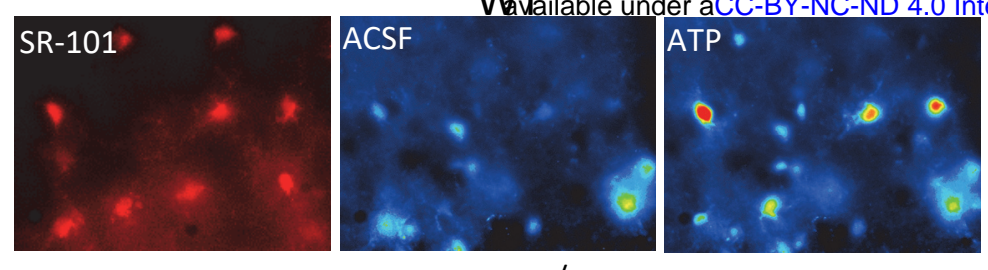

$\mathrm{IP}_{3} \mathrm{R}^{-/-}$
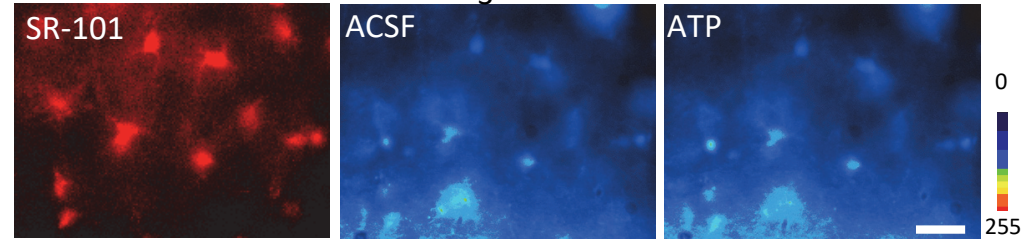
A
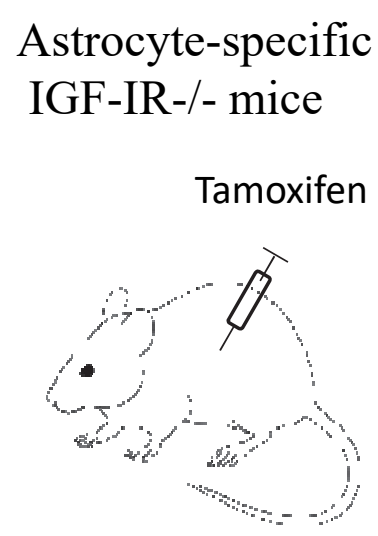

B

GAP crossing test

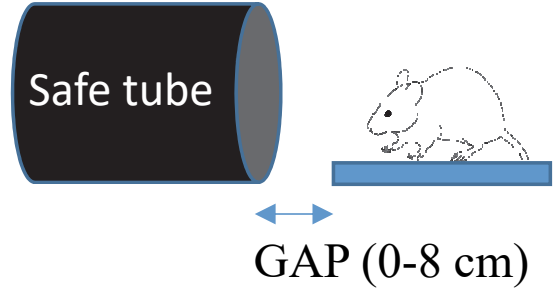

C Y maze alternation test

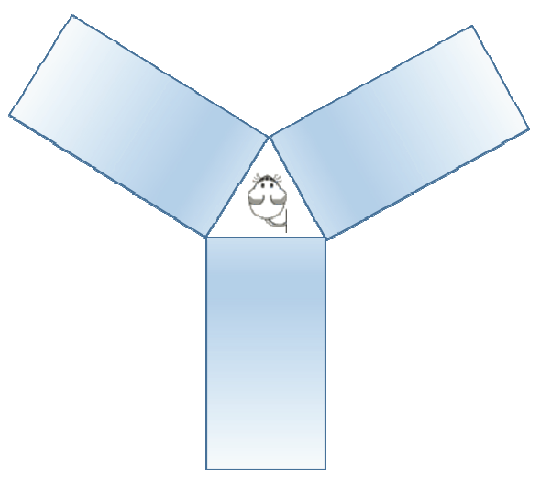

Brain levels of IGF-IR mRNA

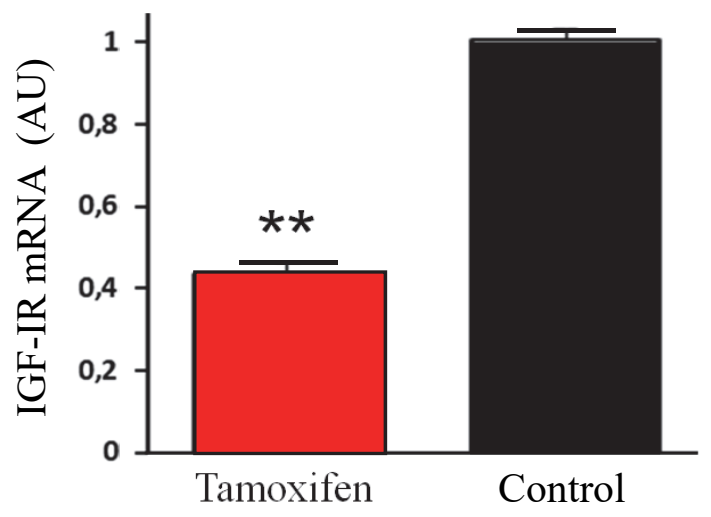

Sensory perception

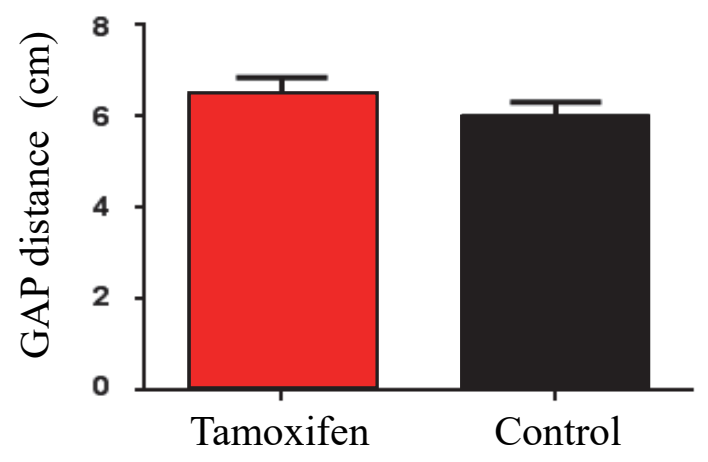

Working Memory

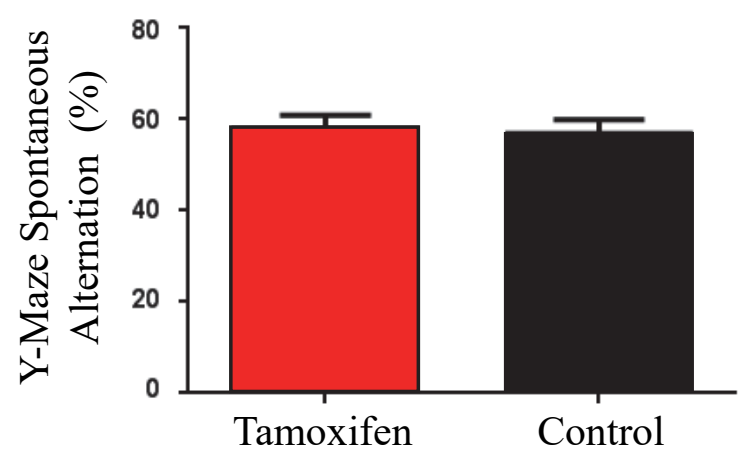

